\title{
Entre arte e propaganda: fotografia e fotomontagem na vanguarda soviética ${ }^{1}$
}

Annateresa Fabris

Escola de Comunicações e Artes da USP

RESUM 0: Técnica que permite praticar uma arte figurativa e, assim mesmo, moderna, a fotomontagem é muito utilizada pelos artistas da vanguarda soviética. Usada, a princípio, em capas de livros e revistas, ilustrações e cartazes, será colocada a serviço dos objetivos do Partido Comunista por artistas como Klutsis, El Lissitki e Rodtchenko.

PA LAVRAS-ChaVE: Arte. Política. Fotografia. Fotomontagem. Vanguarda soviética.

ABSTRACT: A technique that allows for a figurative and yet modern art, photomontage was much used by artists of the So viet a vant-garde. Employed at first in book and magazine covers, illustrations and posters, photomontage later suited the ends of the Communist Party in the hands of artists like Klutsis, El Lissitzy and Rodchenko.

KEYW O RDS: Art. Politics. Photography. Photomontage. Soviet Avant-G arde.

Em meados da década de 1910 , os dadaístas de Berlim, a o aderirem a os processos de monta gem - combinação de imagens fotográficas de diferentes proveniências -, proclamam de uma só vez a morte da arte (tradicional) e a realida de do caos do mundo moderno, introduzindo em suas obras a experiência do choque. Derivada das características fundamentais da metrópole capitalista, tal experiência permite transpor para o interior da obra a percepção de uma transformação cada vez mais veloz, de uma comunicação simultânea, de um hibridismo não alheio à confusão entre real e artístico. A forma, como lembra $M$ anfredo Tafuri, não deve ser mais busca da além do caos, e sim em seu interior, pois é dele que brota uma nova técnica de comunicação, capaz de conferir um novo valor a um universo considerado antes "sem qualidades" 2 .

Também Adorno detecta a experiência do choque na utilização da montagem, mas a reporta não à vivência urbana, e simà ação empreendida pelos artistas contra a "unidade orgânica" da obra. A negação da unidade, da
1. Investigação financiada por uma Bolsa de Produtividade em Pesquisa do CNPq (Projeto: O desafio do olhar: arte e fotografia no período das vanguardas históricas).

2. TAFURI, 1973, p. 78,87 88. A respeito da fotomontagem praticada pelo grupo dadaísta de Berlim, ver FABRIS, 2003, p. 11-57. 
3. ADORNO, 1977, p.260 262.

4. ADES, 1986, p. 63-64.

5. LODDER, 1987, p. 187 síntese e, logo, do princípio configurador coloca em xeque a aparência de reconciliação entre 0 homem e a natureza que estava na base da concepção orgânica anterior ao Cubismo. Ao admitir em seu interior as "ruínas litera is" do mundo empírico, a arte, a partir das colagens cubistas, dá início ao processo contra a obra como "nexo lógico", infligindo "visto sas cicatrizes" a o sentido, que acaba sendo negado no momento em que a unidade é questionada pelo uso de elementos díspares. Adorno encontra uma explicação política para o uso maciço das técnicas de montagem que reporta à consciência da "impotência" da arte diante da totalidade do capitalismo tardio e à vontade de abolir essa dimensão graças à negação da aparência de um continuumª .

Uma outra visão de fotomontagem

A existência de um elo profundo entre as técnicas de montagem e a sociedade capitalista, sublinhada por Tafuri e Adorno, não deve fazer esquecer que um recurso como a fotomontagem é amplamente utilizado na Rússia pósrevolucionária, ganhando significados diferentes em relação às experimentações dos artistas ocidentais.

Essa diferença é a firmada no âmbito soviético por G ustav Klutsis, que discrimina duas correntes no interior da técnica: a fotomontagem formal, derivada do exemplo da publicidade norte-americana, própria dos dadaístas e dos expressionistas; e a fotomontagem militante e política, criação exclusiva da União Soviética. 0 artista fazia brotar 0 caráter único da fotomontagem militante de sua conexão com a política revolucionária, o progresso industrial e tecnológico e as novas formas da cultura de massa. Afirmava ainda que 0 uso da fo tomontagem como novo método de arte datava de 1919-1920, estabelecendo uma prioridade em relaçã 0 às experiências alemã $s^{4}$.

Ao fazer esse tipo de afirmação, Klutsis advoga para si o papel de pioneiro da nova técnica: apresenta Cidade dinâmica como a obra em que a fo tomonta gem foi "utiliza da pela primeira vez como elemento de textura e figuração, de acordo com o princípio das diferentes divisões". C hristina Lodder lembra que há na obra uma inscrição que demonstra o papel pioneiro que Klutsis a tribuía a seu trabalho: "Suprematismo volumetricamente espacial + fotomontagem. A derrocada da não-objetividade e o nascimento da fotomontagem como forma artística independente". 0 uso do termo fotomontagem numa obra datada de 1919 leva a autora a formular duas hipóteses: Klutsis redigiu a inscrição na época da realização de Cidade dinâmica, demonstrando conhecer as experiências alemãs, nas quais seu trabalho se basearia; ou a inscrição pode ter sido acrescentada posteriormente, 0 que comprovaria que 0 artista se limitou a tomar de empréstimo o termo, tendo desenvolvido sua pesquisa de maneira independente 5 . 
Dawn Ades, por sua vez, reporta uma informação de Vassili Rakitin, segundo o qual Klutsis teria usado a fotomontagem pela primeira vez em 1918 no projeto de um painel para o V Congresso dos Sovietes em M oscou. Alexei $G$ an também teria feito experiências com a técnica no mesmo ano, mas é possível, segundo a autora, que nada disso tenha vindo a público, como demonstraria a ausência de cartazes russos feitos a partir da fo to montagem na revista internacional Das Plakat ${ }^{6}$.

Existem duas versões de Cidade dinâmica: uma lança mão da fotomontagem; a outra é um quadro executado em 1919-1920, no qual Klutsis explora a textura material da superfície pictórica graças ao uso de areia, vidro e aparas de metal. Para além desse aspecto, que remete à idéia de faktura, isto é, ao tratamento do material na superfície da tela, que acaba por determinara forma da obra , é possível determinar um princípio comum às duas versões de Cidade dinâmica: a opção por uma composição planimétrica, articulada aos princípios do Suprematismo dinâmico e das composições Proun de El Lissitzki, que fazem com que Klutsis privilegie o uso de uma forma esférica central a partir da qual se projeta um eixo diagonal.

$\mathrm{N}$ a fotomontagem alguns planos geométricos são substituídos por fragmentos icônicos: a superfície de um a rranha-céu norte-a mericano, um a rranhacéu completo e imagens de trabalhadores. As formas geométricas que persistem no eixo diagonal sugerem vigas de aço, enquanto a esfera pode ser vista como o elemento unificador da composição por englobara idéia da construção de um novo mundo graças a o Socialismo. A colocação das figuras dos trabalha dores em diferentes posições é provavelmente uma evocação daqueles elementos flutuantes que caracterizavam as obras do Suprematismo dinâmico. Ao mesmo tempo ela imprime um ritmo rotatório à composição, que poderia ser vista de todos os lados, como o próprio Klutsis recomenda numa inscriçã $0^{8}$.

A estrutura utilizada em Cidade dinâmica está na base de outras fo tomontagens realizadas por Klutsis no final dos anos 1910 e no começo dos anos 1920: 0 velho mundo e o mundo que está sendo construído agora (1920), A eletrificação de todo o país (1920) e Esporte (1922). A concepção radial está presente nas três obras que denotam uma adesão mais franca à lógica fo tográfica. N o caso das duas primeiras imagens há uma explicação para 0 predomínio dos elementos icônicos, visto tratar-se de projetos para cartazes de propaganda. Em 0 velho mundo e o mundo que está sendo construído agora, a estrutura radial ocupa o fundo da fotomontagem, no qual se destacam dois círculos: o menor contém símbolos do regime tsarista (cadeia, correntes, chicote) enquanto o maior abriga imagens de derivação construtiva. Se o círculo do passa do evoca uma realidade estática, o círculo construtivo, a o qual corresponde a imagem de Lenin, é uma forma dinâmica a sugerir um movimento de rotação (Figura 1). 127-133. Ver também: BUCHLOH, 1984, p. 8590.

8. ADES, 1986, p. 67;LODDER, 1987, p. 188; TUPITSYN, 1991, p. 43. 


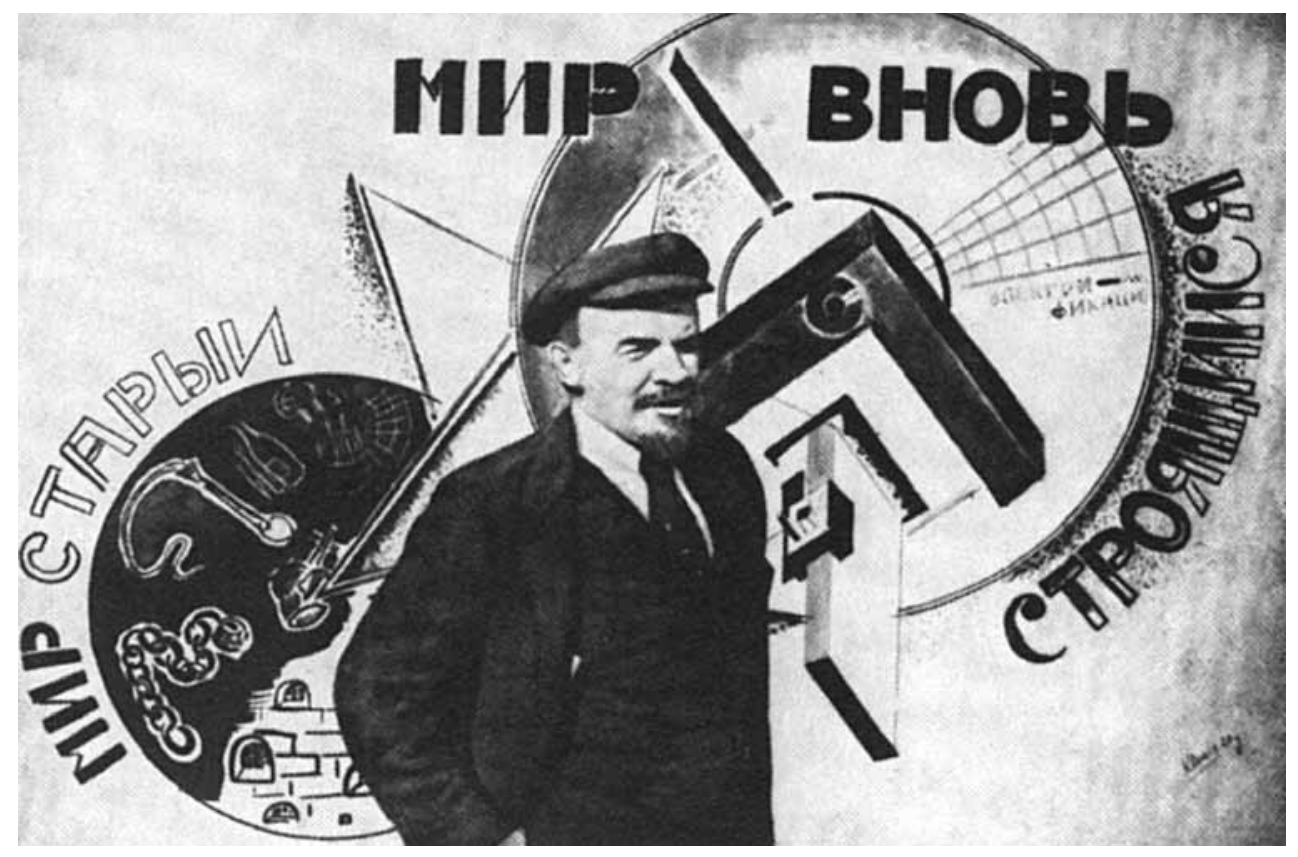

Figura 1 - Gustav Klutsis, 0 velho mundo e o mundo que está sendo construído agora, 1920 (ADES, 1986, p. 68).

Lenin é também protagonista de A eletrificação de todo o país, sugerida pela apresentação de seu Plano para a Eletrificação no VIII Congresso dos Sovietes. Klutsis concebe uma composição capaz de dar conta do programa de industrialização e modernização formulado pelo líder político: a imagem de Lenin carregando uma espécie de andaime metálico, do qual sobressa i uma estrutura a rquitetônica, domina a parte superior da fotomontagem. O lhando para a frente, Lenin adentra num círculo do qual se irradiam formas geométricas que simbolizam o progresso.

A idéia de dinamismo confiada à diagonal, que fora determinante em Cidade dinâmica, é retomada em Esporte. Diversos círculos concêntricos, que se irradiam do fundo, no qual a palavra "esporte" está grafada com tipos góticos, acolhem a diagonal formada pelo encontro de dois aparelhos de ginástica. 0 efeito óptico sugerido pelos círculos imprime um forte movimento rotatório à composição, evocando a possibilidade daquela visualização não unívoca que já caracterizava Cidade dinâmica.

Uma opção estratégica

Para compreender as razões do predomínio cada vez maior de elementos icônicos nas fotomontagens de Klutsis é necessário a nalisar o papel conferido à fotografia pela vanguarda soviética. Um artigo dedicado à 
fotomontagem, publicado em 1924 na revista de vanguarda Lef, fornece uma visão significativa daquilo que os artistas da União Soviética demandavam à nova técnica. Partindo da definição da fotomontagem como "a utilização do instantâneo fotográfico como meio visual", o artigo logo assinala sua superioridade em relação às técnicas tradicionais:

A combinação de instantâneos toma o lugar da composição numa representação gráfica. Essa substituição significa que o instantâneo fotográfico não é o esboço de um fa to visual, mas seu registro preciso. Essa precisão e o caráter documentário do instantâneo têm um impacto no observador que nenhuma representação gráfica consegue atingir.

A importância conferida à natureza factual da fotografia como instrumento de construção de uma visualidade comprometida com a causa revolucionária está também presente num texto de Varvara Stepanova datado de 1928 . Ao conceder primazia às fotomontagens realizadas por Aleksandr Rodtchenko a partir de fotografias de própria autoria, a artista estabelece uma relação precisa entre essa tendência, que busca "uma totalidade independente e completa", e o valor documentário da fotografia, capaz de fornecer uma "informação precisa" sobre o tempo e o lugar das imagens apresentadas. Stepanova não deixa de assinalar um problema provocado por esse tipo de produção: "a necessidade de uma técnica para expressar a realidade em termos característicos e explícitos"10.

Uma visão bem mais articulada das possibilidades da fotografia pode ser encontrada no livro $A$ arte de hoje, publicado por $\mathrm{N}$ ikola i Ta rabukin em 1925. N essa coletânea de ensaios, em que são a nalisadas as artes do cotidiano - publicidade, design, cartazes, estamparia, produção gráfica -, Ta rabukin concede um espaço privilegiado à problemática da fotomecânica, atraído por suas qualidades reprodutivas e, sobretudo, pela possibilidade de desnaturalizar o naturalismo e de colocar as novas imagens a serviço da agitação e da propaganda.

Interessado nas imagens técnicas que negam a fotografia "cruamente naturalista", o a utor enfatiza em seu ensa io as diferentes estra tégias de sup eração da verossimilhança, entre as quais a fotomontagem. Definindo a fotomontagem como "UM ESTÁGIO NA PIN TURA, que começou a utilizar o poder mecânico da câmara em lugar de um desenho feito "pela mão'", Ta rabukin não hesita em sublinhar sua relação intrínseca com as tendências artísticas "de esquerda", sobretudo com o princípio planimétrico.

Uma outra observação presente no ensaio fornece elementos para compreender a opção feita por artistas como Klutsis, Rodtchenko e El lissitzi:

A fotomontagem só apareceu na frente da arte de esquerda quando a abstração já tinha feito seu curso [...]. A fotomontagem veio à luz a través do aspecto de agitação da arte moderna. M as o artista a usou de um modo diferente do naturalista. 0 fotomontador não vê a arte representativa como um fim, como o naturalista, mas apenas como um meio. Por essa razão torna-se mais uma vez um artista representativo, mas, sem porisso, virara casaca. Seu caráter representativo constitui formalmente um novo elemento na obra de arte que, de modo algum, coincide com o papel estético da representação nos quadros dos naturalista $s^{11}$.
9. STEPANOVA, 1989, $\mathrm{p}$. 211-212. Phillips e MargaritaTupitsyn afirmam que esse artigo, publicado sem assinatura, pode ser atribuído a Klutsis.

10. Id., p. 236.

11. TARABUKIN, 2000, p. 68-69. 
12. TARABUKIN, 1977, p. 40 .

13. Id., p. 47-48.

14. Id., p. 72-73.

15. Id., p. $43-45$
0 uso recorrente do termo "naturalismo" merece uma explicação. Tarabukin reserva a palavra "realismo" para os trabalhos da vanguarda russa, sobretudo os de derivação construtivista, caracterizados pela ênfase dada à forma da obra:

0 artista constitui nas formas de sua arte sua própria realidade e concebe o realismo como consciência do objeto autêntico, autônomo em termos de forma e conteúdo. Esse objeto não é uma reprodução das coisas do mundo exterior, mas é construído, de ponta a ponta, pelo artista fora das linhas de projeção que poderiam vinculá-lo à realidade ${ }^{12}$.

Embora defenda as razões do realismo contra as do naturalismo, Tarabukin não se furta a assinalar em Do cavalete à máquina (1922) a crise pela qual estava passando a arte contemporânea, motivada pela percepção da "inconsistência" da "forma pura desprovida de todo conteúdo". N uma sociedade em que a democratização estava pondo fim à separação em classes, não havia mais razão para a existência do quadro "como forma típica de arte visual". 0 público de massa, que havia surgido do processo revolucionário, não pedia à arte "as variações sem fim, a dispersão e a individualização", próprias do quadro feito no ateliê. Ao contrário, "exige da arte formas que expressem as idéias das massas, da sociedade, do povo em seu conjunto". Diante dessa nova realidade, o papel do artista modifica-se substancialmente: cabe-the produz ir "objetos justificados socialmente por sua forma e utilidade"13.

Partidário da plataforma produtivista, Ta rabukin acredita que a função do artista acabará por coincidir com a organização do trabalho produtivo. Por isso defende a "mestria produtivista", na qual "a arte e a técnica se confundem. A técnica transforma-se em arte quando se tende conscientemente à perfeição. [...] A mestria produtivista é funcional, construtivista em sua forma e coletivista no ato processual-criador ${ }^{\prime \prime 14}$.

Por isso também localiza em Cor vermelha pura (1921), de Rodtchenko, a destruição da pintura:

Era uma pequena tela quase quadrada, completamente coberta de uma única cor vermelha. Essa obra é extremamente significativa da evolução seguida pelas formas artísticas no decorrer dos últimos 10 anos. $\mathrm{N}$ ão se trata mais de uma etapa, mas do último passo, 0 passo final de um longo caminho, a última palavra depois da qual a pintura deverá guardar silêncio, o último "quadro" executado por um pintor. Essa tela demonstra eloqüentemente que a pintura como arte da representaçã 0 - 0 que sempre foi a té o presente - chegou ao final do caminho. Se o quadrado negro sobre fundo branco de $M$ alevitch continha, apesar da pobreza de seu sentido estético, uma certa idéia pictórica que o autor havia chamado de "economia", "quinta dimensão", a tela de Rodtchenko, a o contrário, está desprovida de todo conteúdo: é um muro cego, estúpido e sem voz. [...] Ao deixar de ser representativa, a pintura perdeu seu sentido interno. 0 trabalho de laboratório sobre a forma pura encerrou a arte num círculo estreito, deteve seu progresso e a levou a o empobrecimento ${ }^{15}$.

A afirmação de Tarabukin não pode ser dissociada de sua crença na natureza representativa do Construtivismo. 0 autor, de fato, detectava nas construções planas realizadas pelos construtivistas "a representação de um 
mecanismo ou de um sistema construtivo que podia ser realmente construído". Ao contrário, a cor, elemento informe, não se incluía em nenhuma forma de representaçã $0^{16}$, daí Cor vermelha pura, Cor amarela pura e Cor azul pura, apresentadas por Rodtchenko na exposição "5 x $5=25$ " (1921), serem consideradas atestados de morte da pintura.

Rodtchenko, de resto, vinha se afastando da pintura de cavalete desde 1919, voltando-se para a construção de formas matérico-tridimensionais, ou pesquisando as qualidades autônomas dos pigmentos. Entre 1920 e 1921 realiza uma série de construções plástico-a rquitetônicas - estruturas geométricas suspensas no espaço, feitas de materia is como madeira, papelão e compensado - que propõe uma troca de função entre arte e decoração. N esse momento, declara a superação do pincel e a necessidade de lançar mão dos "novos instrumentos da técnica moderna" para a configuração da arte do futuro, isto é, da arte de uma sociedade transformada pela industrialização. Rodtchenko está propondo, desse modo, um projeto artístico articulado a o crescimento tecnológ ico da sociedade comunista: por isso é necessário que o artista se liberte da pintura tradicional e do uso decorativo da forma para engajar-se num sistema de trabalho criativo, no qual a forma está associada à matéria e a seus usos estruturais e funcionais.

As telas a presentadas na exposição de setembro de 1921 - superfícies monocromáticas, nas quais é a firma da a pureza a nalítica do ma terial - confrontam o espectador com o limite máximo da pintura nã o-objetiva. Com elas, Rodtchenko demonstra que numa superfície plana só pode ser aplicada uma única cor, sem qualquer forma, posto que ela própria é forma. Ao mesmo tempo em que abre caminho para uma nova concepção de pintura, dissociada de todo símbolo psicológico e de todo sentimento pictórico, avessa a toda concepção mimética, o artista declara o fim da arte pura como possibilidade de uma prática revolucionária ${ }^{17}$.

A a titude de Rodtchenko está profundamente enraizada no debate cultural que se havia instaurado na Rússia depois da Revolução de 0 utubro de 1917. A condenação do quadro de cavalete não é apenas uma tomada de posição contra uma forma de arte considerada ultrapassada e inadequada a representar a nova realidade revolucionária. 0 quadro de cavalete é atacado por uma razão bem mais precisa: a necessidade de mudar a propriedade dos meios de produção. Boris Arvatov demonstra claramente a impossibilidade da existência de um quadro de cavalete proletário em função da origem classista desse tipo de suporte:

Um quadro de cavalete, independente de seu conteúdo, será sempre um produto da arte burguesa, mesmo que o tenha pintado um proletário; por ser de cavalete e por ser quadro, nunca se transformará em proletário.

Pensar no impacto ideológico proletário de um quadro de cavalete é um erro, precisamente pela forma do quadro. Impossível de ser fabricado em série, de ser multiplicado, desligado de to da função social prática, situado de ma neira to talmente ca sual, o quadro é organicamente incapaz de surtir o efeito que dele se espera, portanto não vale a pena pintá-10. Delacroix,
16. TARABUKIN, 1977 , p. 43.

17. FINIZIO, 1990, p.131132, 135; NAKOV In: TARABUKIN, 1977, p. 3334. 
18. ARVATOV, 1973 p. 57-58.

19. Id., p. 64

20. Id., p. 101-103

21. HOFMANN, 1971 p. 204; ARVATOV, 1973 p. 118-119. que pintou uma barricada, prestou o mesmo serviço ao movimento revolucionário francês que $\mathrm{G}$ éricault com seus cavalos de corrida ${ }^{18}$.

Fiel a esse pressuposto, Arvatov não hesita em apontar 0 erro dos artistas construtivistas no período que antecedeu a revolução. Interessado na transformação artística dos materiais, 0 artista novo acredita ser "criador de um mundo independente de formas, quando, na verdade, se atola cada vez mais no mundo do objetivo em si, sempre preso a o cavalete". Após a revolução, percebeu, porém, a tarefa que lhe cabia: a transformação dos materiais será "uma grande força organizadora se for ap licada à criação de formas necessárias, utilitárias de objetos"19.

Rodtchenko engaja-se ativamente naquela vertente de produção artística que Arvatov denomina de "industrialismo", desejoso, antes de tudo, de conferir uma função social à arte. N essa perspectiva, a arte não pode estar dissociada do processo produtivo, daí a condenação do quadro de cavalete como relíquia do sistema artesanal. Inserido numa nova realidade, 0 artista terá como tarefa primordial a construção da vida diária, participando da produção dos "meios de consumo produtivo", ou seja, dos transportes, das construções, do vestuário, dos utensílios de cozinha, da literatura prática, etc. Integrante do processo produtivo, o artista será um "engenheiro desenhista", capaz de elaborar uma nova linguagem a partir dos novos meios de produçãa ${ }^{20}$.

M uitos artistas filiados ao Instituto de Cultura Artística de M oscou, entre os quais Rodtchenko, aderem à plataforma produtivista, abandonando 0 terreno da arte pura para trabalhar em conta to direto coma indústria. 0 entusiasmo dos artistas é, de certo modo, refreado pelas diretrizes da N ova Política Econômica (1921-1927), que permite reconstruir 0 apara to industrial e a rede de transportes e comunicações anteriores à revolução, reservando, porém, um espaço ainda pequeno a o planejamento sistemático do desenvolvimento futuro. Uma vez que o objetivo fundamental da política econômica é a "acumulação originária", a população não pode contar, de início, com um incremento do consumo, pois faltava 0 que era essencial nesse sentido: novos métodos de produção industrial e de distribuição. No campo cultural, a falta desses requisitos básicos é explicitamente reconhecida por Arvatov, que localiza os maiores resultados do ind ustria lismo na literatura, no tea tro, na cinema to grafia (por não necessita rem tanto de instalações tecnológicas) e na arquitetura (em virtude do esforço construtor que estava tomando conta do país). Se 0 atraso da indústria e as dificuldades financeiras do Estado haviam sido um obstáculo ao desenvolvimento das artes plásticas, assim mesmo Arva tov enumera um conjunto de realizações expressivas: cartazes, cenografia e poligrafia, nas quais foi criado "um estilo de montagem"21.

Além das dificuldades advindas de um sistema industrial pouco desenvolvido, que acaba levando os artistas plásticos apenas para 0 design, os produtivistas vêem-se às voltas, a partir de 1922, com a doutrina do "realismo heróico", formulada pela Associação dos Artistas da Rússia Revolucionária. $0 \mathrm{~s}$ objetivos do grupo, apresentados na Decla ração de junho de 1922, embora genéricos, eram claramente políticos. Os artistas da associação não só 
propunham a representação da vida atual, como tinham focos bem determinados: o Exército Vermelho, os operários, os camponeses, os líderes revolucionários, os heróis do trabalho. Além da vida desses personagens, esta vam voltados para a representação do "dia da Revolução" e do "momento da Revolução" nas "formas monumentais do estilo do realismo heróico". Apresentando-se como os portavozes da "vida espiritual do povo", os pintores da associação estavam determinados a oferecer "um retrato verdadeiro dos fatos, e não tramas abstratas desmerecendo nossa Revolução diante do proletariado internacional". Esses propósitos estão cla ramente explicitados nas várias exposições organizadas pelo grupo que tiveram como tema a industrialização (1923), o Exército Vermelho (1922, 1923 e 1928), a vida revolucionária e o trabalho $(1922,1924$ e 1925), entre outros. A aproximação com o renascido grupo dos Errantes, igualmente contrá rio à s tendências anti-realistas, propiciou, por outro lado, a retomada da retratística e das cenas de gênero ${ }^{22}$.

A polêmica contra os Produtivistas tem um de seus maiores representantes em Eugeni Katsman. Ele não só os considera "pintores de pequeníssimos grupinhos", como coloca em dúvida seus propósitos revolucionários, por serem discípulos de mestres como C ézanne, Picasso, M atisse e M arinetti, "ideólogos de grupúsculos de intelectuais burgueses do período de tensão capitalista, de contradições nervosas, do período em que 'o martelo do antagonismo capitalista' forjou a consciência individualista"23.

A ofensiva realista contra o Produtivismo não é um fato isolado, vem amparada pela hostilidade contra os movimentos modernos que se tornava cada vez mais evidente no âmbito oficial da revolução. Já em 1920 Lenin polemiza com as tend ências da a rte moderna e com sua pla ta forma futurista, po is a credita va que a cultura estava enraizada dialética e organicamente no passado. Só explorando ao máximo o legado da cultura burguesa era possível construir uma cultura proletária, isto é, uma cultura que pertencesse ao povo e que fosse compreendida pelo homem médio. Uma vez que as vertentes modernas, entre as qua is o Construtivismo, não eram a cessíveis a esse homem, Lenin consideraas totalmente inadequadas para a configuração da a rte marxista. Além disso, a arte abstrata negava a significação do mundo material da natureza e da sociedade humana que, em sua visão, integravam uma única realidade.

A opção por uma linguagem realista, inspirada pelo Realismo progressista da segunda metade do século XIX, não responde apenas a um gosto pessoal. Se Anatoli Luna tcharski lembra que Lenin gostava dos clássicos russos e do "realismo na literatura, na pintura, etc.", o que é de fato determinante na adoção de uma plataforma realista é a função propagandística em termos sociais e partidário que o líder revolucionário atribuía à arte ${ }^{24}$.

Essa diretriz é claramente explicitada na política cultural do governo bolchevique por meio de um porta-voz como Lunatcharski, comissário do povo para a Instrução Pública. N um artigo intitula do "A revolução e a arte" (1922), Lunatcharski confia à revolução a tarefa de salvar a arte do "pior tipo de decadência" - o formalismo -, devolvendo-the "seu destino a utêntico: a poderosa e contagiosa expressão das grandes idéias e das grandes vivências". Se a
22. NEGRI, 1989, p. 147148; WOOD In: FER, 1998, p. 275-276; LODDER, 1987, p. 184-185. 0 grupo dos Errantes constituiu-se em 1863, quando 13 artistas (entre os quais Mark Antokoski e Vassili Polenov) rompem com a Academia, inspirados pelo ideal de levar a arte ao povo por intermédio de exposições que alcançassem as regiões agrícolas do país. Por acreditar que a arte era uma força ativa na transformação da sociedade, 0 grupo dá grande ênfase à representação heróica do camponês e à austeridade de sua vida e, para tanto, adota uma linguagem de cunho realista. Em nome do realismo, os Errantes opõem-se ao Neoclassicismo internacional, que imperava na Rússia desde o fim do século XVIII e que era a linguagem oficial do ensino acadêmico.

23.Apud ARVATOV, 1973, p. 114-115.

24. EGBERT, 1973, p. 42 44, 47-48; LUNACHARS$\mathrm{KI}, 1969$, p. 7 . 
25. LUNACHARSKI, 1969 p. 68-69.

26. Id., p. 71, 74

27. Id., p. 83,97

28. Id., p. 169.

29. Cf. LODDER, 1987 p. 181;ADES, 1986, p. 76; BUCHLOH, 1984, p. 95. revolução é um precioso a uxiliar da arte, esta, por sua vez, deve ajudar o Estado a "difundir o gênero revolucionário de idéias, de sentimentos e de ações por todo o país". 0 que significa que a arte deve converter-se em propaganda:

Q uem não conhece a força da propaganda? 0 que é a propaganda, em que se diferencia da clara, mas um tanto fria publicidade, da exposição objetiva e metódica de fatos e de construções lógicas?

A propaganda diferencia-se da publicidade por, antes de tudo, inquietar os sentimentos de quem a ouve ou lê, e influir diretamente sobre sua vontade. Em outras palavras, exalta 0 conteúdo da mensagem revolucionária e o obriga a resplandecer com todas as cores. [...] o grande propagandista coletivo que é o Partido Comunista deve dispor de todos os meios da arte que, dessa forma, se converterá em poderoso esteio da propaganda. N ão só os cartazes, mas também, de uma forma menos fugaz e contendo idéias mais profundas, os quadros e as esculturas podem resultar, por assim dizer, no meio patente para a assimilação da verdade comunista ${ }^{25}$.

A associação entre arte e propaganda faz com que Lunatcharski, embora não negando a qualidade das obras produzidas pelos artistas de vanguarda, as considere inadequadas à revolução. $0 \mathrm{~s}$ trabalhos dos artistas das novas tendências "eram mais adequados à indústria e à ornamentação artística" e "impotentes para expressar o novo conteúdo ideológico da revolução", a exigir "uma expressão realista, uma forma transparente, saturada de idéias e de sentimentos". 0 interesse do governo em promover uma arte de fácil decodificação leva-o a desenvolver duas ações paralelas: a salvaguarda do "que havia de melhor na arte antiga, pois sua assimilação é necessária aos futuros passos da arte renovada" e 0 apoio a toda inovação "que seja útil ao desenvolvimento das massas populares"26.

Esse clima cultural, no qual a arte é concebida como "ilustração político-social", como propaganda, a não ser nos momentos em que está a serviço da indústria ${ }^{27}$, é propício à revalorização de uma pintura objetual e realista, que se opõe ao experimentalismo técnico-formal graças a uma figuração nitidamente antivanguardista. Diante dessa campanha sistemática contra as novas tendências, condenadas por se afastarem do "discurso humano"28, a opção de Klutsis pela fotomontagem demonstra ser uma escolha acertada, pois Ihe permitia salvaguardar algumas conquistas fundamentais das vanguardas soviéticas e satisfazer ao mesmo tempo a demanda por uma arte ideológica de caráter icônico. Seu exemplo será seguido por outros artistas de vanguarda que se voltam para a fotografia e sobretudo para a fotomontagem como uma maneira de reintroduzir a iconicidade na representação plástica sem que fossem necessários o retorno de uma figuração naturalista e a mediação de velhas técnicas ${ }^{29}$.

N esse contexto não faltam críticas à Associação dos Artistas da Rússia Revolucionária, cujas pretensões realistas haviam sido colocadas em xeque pela fotografia. 0 ssip Brik estabelece uma clara distinção entre a tarefa do fotógrafo, que é a de documentar a vida, e a do pintor, que consiste em recriar o objeto a partir de leis puramente pictóricas. Por isso, a pintura realista parece-lhe um esforço vão, embora motivado por três fatores sociais: 0 interesse por uma 
documentação da nova vida, o alto índice de desemprego dos pintores, a decadência do nível artístico do público "incapaz de distinguir entre uma representação precisa da natureza e outra muito aproximada". Em sua defesa extrema da fotografia, Brik não deixa de atribuir-lhe uma funcionalidade que deveria colocá-la ao abrigo das novas investidas da pintura: "0 fotógrafo registra a vida e os acontecimentos de um modo mais barato, mais rápido e mais preciso que o pintor. $\mathrm{N}$ isso residem sua força, sua grande significação para a sociedade. $\mathrm{N}$ enhuma recaída nos primitivos métodos pictóricos o a pavora. ${ }^{\prime 30}$

O s artistas das novas tendências, mesmo contribuindo para a construção de uma arte popular e nacional, que respondia à necessidade de representar um conteúdo "a mplo, monumental, espontâneo, eterno e grandioso"31, gua rdam em suas composições fo to gráficas ou de derivação fo tográfica muitos dos princípios construtivistas, que aplicam a cartazes, capas de revistas e de livros, publicidade, entre outros.

Rodtchenko e a fotomontagem

As primeiras experiências de Rodtchenko com a fotomontagem estã o, entretanto, mais próximas dos princípios construtivistas do que de uma retórica popular. É o caso do projeto da capa do número um e dois da revista Lef (1923), determinada por uma organização de caráter construtivo. Um retângulo preto aberto na base serve de moldura a dois dos instrumentos que revolucionaram a comunicação moderna: uma máquina de escrever e, em primeiro plano, uma objetiva ladeada à esquerda por uma câmara. A objetiva e a câmara são colocadas entre os algarismos 1 e 2 reproduzidos em vermelho, formando um contraste cromático com eles, uma vez que são pretas por sua origem fotográfica. 0 contraste cromático é retomado no nome da revista, preto na parte superior e vermelho na inferior. Esse tipo de solução gráfica já havia sido ensaiado pelo artista nas capas de Kino-fot (1922), nas qua is as letras são usa das como elementos construtivos. É nessa revista que Rodtchenko divulga seu primeiro trabalho com a técnica da fotomontagem: a capa para o livro de poesias de Ivan A ksionov, intitula do As colunas de Hércules (1920).

A geometrização rígida, que está na base dessa primeira experiência, não é a marca distintiva de seu trabalho mais bem sucedido com a nova técnica: a capa e as ilustrações para o poema de Vladimir M a iakóvski, Sobre isso (1923). Embora Rodtchenko retome um aspecto fundamental de sua poética construtivista - o uso da linha como elemento que delimita os planos e propicia uma construção bidimensional -, o resultado é uma composição fluida, para a qual convergem imagens de diferentes proveniências: anúncios publicitários, material de revistas e jorna is e fotografias pessoais de Maiakóvski e Lília Brik, a inspiradora do poema.

0 autor das imagens pessoais de Maiakóvski e Lília Brik não é Rodtchenko, mas um fotógrafo profissional, Abram Shterenberg, que atua sob a
30. BRIK In: PHILLIPS, 1989, p. 215. Lunatcharski, ao contrário, confere primazia à pintura do grupo, que considera superior às possibilidades oferecidas pela fotografia. Cf. LUNACHARSKI, 1969, p. 166.

31. LUNACHARSKI, 1969 p. 43 . 
32. NAKOV, 1977, p. 40.

33. MARGOLIN, 1997, p. 107.

34.Id., p. 108. direção do artista. Por isso, a imagem da capa, que é antes uma colagem do que uma fotomontagem, é reportada por Andrei $\mathrm{N}$ akov à militância não-objetiva de Rodtchenko, patente na perfeita simetria da composição, na frontalidade absoluta a ssumida por Ĺlia Brik e na bidimensionalidade obtida com a elimina ção do plano de fundo ${ }^{32}$.

0 uso de fotografias do poeta e da amante, entremeadas porimagens contextuais, é motivado pelo caráter profundamente pessoal de Sobre isso, no qual Maiakóvski faz a defesa da liberdade pessoal numa sociedade revolucionária e dá livre vazão a seu amor por Ĺlia Brik. De acordo com Victor M argolin, Rodtchenko concebe o poema como um texto teatral, do qual ele seria o diretor. M a iakóvski e Ĺlia Brik são fotografados em vários momentos por serem os a tores da peça, para a qual o artista traz elementos realista s estabelecendo um elo com a vida do poeta ${ }^{33}$. Um elemento realista são, por exemplo, os algarismos 6 7-10, que comparecem na segunda prancha, pois correspondem ao número telefônico de Ĺlia Brik.

A justaposição de imagens realizada por Rodtchenko não é casual nem arbitrária. Em termos estruturais, é possível perceber a presença de um princípio organizador graças a uma linha (invisível) que estabelece um elo entre 0 a cúmulo de imagens e o fluxo do texto, ilustrado num sentido não convencional. Rodtchenko tenta interpretar de maneira dinâmica as imagens que a leitura do poema evoca: o dinossauro e os ursos polares, que figuram na segunda e na terceira pranchas, correspondem a trechos específicos do poema, nos quais M aiakóvski faz referência aos ciúmes provocados por Lília Brik, que transformam sua fala ao telefone num "monstro dos tempos trogloditas" e convertem o a mante num urso. 0 tamanho dado ao telefone e ao dinossauro, que sobrepujam as imagens do poeta e da empregada, é aproximado por Margolin da montagem de atrações, proposta por Eisenstein no mesmo período. Se é próprio da montagem de atrações produzir a construção de uma ação, Rodtchenko propõe a o leitor não um mergulho no trabalho de Maiakóvski, e sim um conjunto paralelo de elementos que lhe permitiriam perceber as tensões e direções do poema. N 0 caso específico da segunda prancha, isso seria proporcionado pelo tamanho díspardas imagens e pela presença incongruente do dinossauro a o lado do poeta que gerariam um efeito de distanciamento ${ }^{34}$ (Figura 2 ).

As fotomontagens concebidas para Sobre isso, por não se pautarem por um desenvolvimento coerente em termos visuais e narrativos, podem ser a proximadas das experiências dadaístas. Rodtchenko lança ainda mão da técnica para executar algumas capas de livros. Para M udança de tudo (1924), coletânea de poemas construtivistas, propõe uma composição tridimensional, caracterizada por diferenças de escala bem marcantes. Para Sífilis (1926), de Maiakóvski, utiliza a imagem negativa de um rosto masculino, à qual sobrepõe um círculo branco atravessado pelo título, na altura dos cabelos, para sublinhar a crítica do poeta à sociedade capitalista. Para Materialização do fantástico (1927), de llya Ehrenburg, realiza um outro tipo de experiência: trabalha simultaneamente com uma imagem positiva e uma imagem negativa da esposa Varvara Stepanova. A imagem positiva constitui a base da fotocomposição. A 


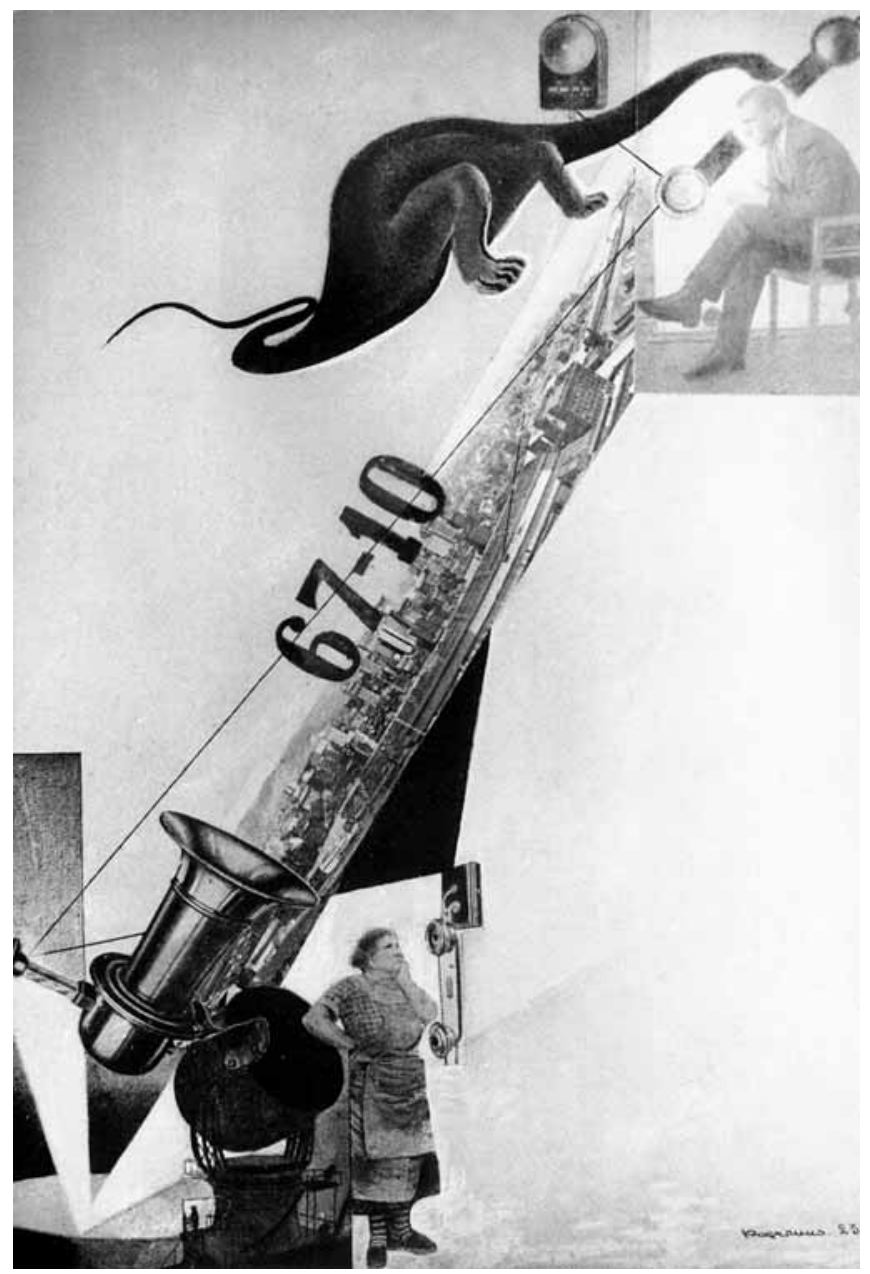

Figura 2 - Aleksandr Rodtchenko, Sobre isso, 1923 (M ARG 0 UN , 1997, p. 110).

ela, na parte central, sobrepõe uma faixa em negativo, o que lhe permite realçar o nariz e a boca e criar um efeito de estranhamento nos olhos. $\mathrm{N}$ a capa e na contracapa de um outro livro de M aiakóvski, Para Sergei Essenin (1926), valese de suas próprias foto grafias experimenta is de imóveis e pontes de ferro. Como Essenin fora um cantor da vida camponesa, as fotomontagens realizadas por Rodtchenko sublinham o conflito entre a vida natural e a vida urbana transformada pela tecnologia graças à sobreposição de um feixe de espigas a uma ponte ferroviária e de uma casa de campo a um detalhe de um edifício moderno visua lizado em diagonal. $N$ enhum desses trabalhos responde a os pressupostos de uma arte ideológica. Todos eles desnorteiam o leitor com seus saltos ou com uma proposta alegórica, longe da idéia de uma visualidade de fácil decodifica ção.

Se o engajamento político e social não é a nota dominante dessas primeiras fotomontagens, Rodtchenko tem condições de provar sua proximidade 
35. Apud MARGOLIN 1997, p. 113 das diretrizes oficiais numa série de trabalhos publicitários e na produção de cartazes e de capas para livros de apelo popular. Em colaboração com M aiakóvski, rea liza entre 1923 e 1925 cartazes para empresas estata is e para a loja de departamentos G UM, lançando as bases dos "primeiros a núncios realmente soviéticos, que se voltavam contra as cabecinhas, as flores e outros ouropéis, em voga no período da N ova Política Econômica" ${ }^{\prime 35}$. N esses trabalhos, reproduzidos em litografia e off-set, Rodtchenko lança geralmente mão de um desenho simplificado, não raro rudimentar, para atingir uma comunicação imediata e sem qualquer tipo de ambigüidade. Em alguns momentos, quando utiliza um procedimento como a colagem, consegue efeitos mais dinâmicos, que evocam o fluxo visual das fotomontagens. A simplificação do desenho, bem como a planaridade da superfície cromática, a separação entre texto e imagem e a introdução de pontos de exclamação e flechas visam a proporcionar uma maior clareza formal e comunicativa. Em busca de um impacto visual imediato, - artista abandona a representação perspéctica, propondo imagens absolutamente bidimensionais.

Embora a lógica da fotomontagem não esteja ausente de muitos trabalhos publicitários, caracterizados pelo uso de um fluxo de imagens ligadas entre si por elementos gráficos, Rodtchenko utiliza explicitamente a técnica no cartaz de Cine-olho (1924), de Dziga Vertov, e nas capas dos livros da série M ess M end (1924), de Jim Dollar (pseudônimo de M arietta C haguinian). Tanto o cartaz do filme de Vertov quanto as capas dos livros de detetive distinguem-se pelo uso de um padrão de derivação construtivista. As imagens fotográficas são inseridas numa estrutura equilibrada, na qual os elementos gráficos são controlados em termos de ta manho e de disposição para não entra rem em choque com os elementos icônicos. Em Cine-olho, a imagem do olho humano se metamorfoseia com a do olho da câmara, sendo o elemento determinante da composição. Para a série $M$ ess $M$ end, Rodtchenko concebe uma capa padronizada: um hexágono, no qual são inseridas, a cada vez, imagens fragmentárias que compõem uma narrativa visual de apelo imediato, encimada porflechas direcionais, pelo número do volume, pelo título e pelo nome do autor. $0 \mathrm{~s}$ elementos gráficos ajudam a reforçar 0 efeito icônico, agem como uma espécie de moldura a realçar um fluxo de imagens sem um centro determinado e sem um princípio hierárquico organizador. Uma vez que 0 artista não encontra nas revistas ilustradas todo o material necessário à construção dos diversos momentos da narrativa de Dollar, que tem como protagonistas operários nortea merica nos empenhados em desvendar um complô interna cional anti-so viético, utiliza como modelos para a confecção do material complementar a mãe, a esposa e os amigos, além de ele próprio encarnar a figura do detetive que comparece na capa do oitavo volume (Figura 3 ).

Esse tipo de produção demonstra que Rodtchenko está tentando fazer de cartazes e capas instrumentos de configuração de uma nova visualidade, não distante de preocupações de transformação social. U ma nova modalidade de fotomontagem, porém, 0 aproxima ainda ma is das diretrizes oficiais. A partir de 1924,0 artista torna-se fotógrafo e começa a utilizar suas próprias imagens 

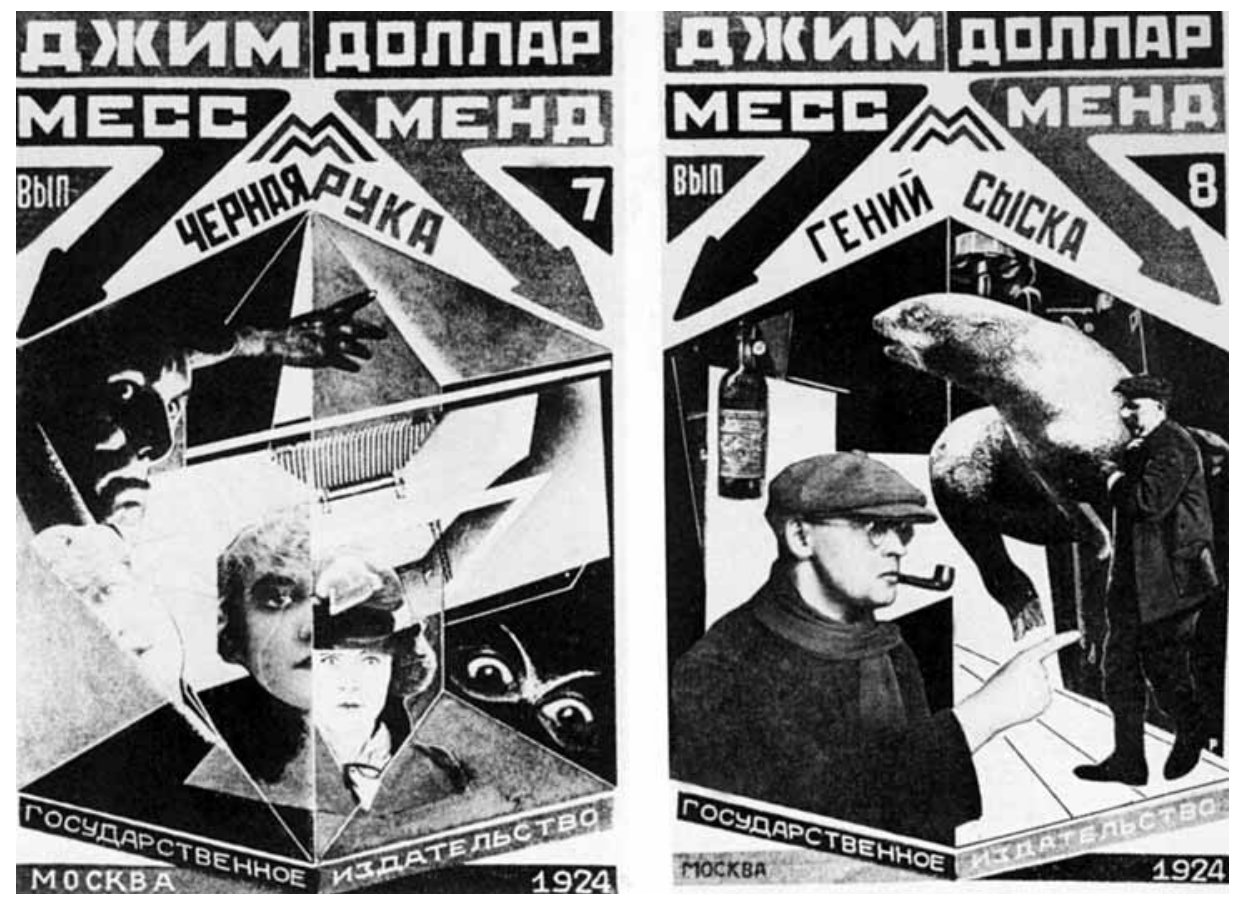

36. STEPANOVA, 1989. p. 236.

37. Em 1922, Lissitzki realiza quatro montagens, nas quais utiliza desenho, aquarela e elementos fotográficos, que servem de ilustração ao livro de Ehrenburg Seis histórias com finais simples. Embora motivado pelo exemplo dadaísta, o artista não deixa de lado os planos geométricos que caracterizavam seus Prouns. A lógica da fotomontagem é aplicada ao fotograma Auto-retrato: o construtor (1924), no qual Lissitzki opera com uma justaposição de elementos, deixando de lado proporções de escala e a estrutura perspéctica convencional.

Figura 3 - Capas para os livros da série M ess M end de Aleksandr Rodtchenko, 1924 (ADES, 1986, p. 85).

na realização das fotomontagens. Cria, assim, uma nova modalidade de composiçã o: deixa de lado a fragmentação das primeira s experiências e estrutura suas fotomontagens a partir da combinação de fotografias ou conjuntos de fotografias individuais. Varvara Stepanova apresenta uma justificativa ideológica para esse novo momento:

0 próprio artista deve realizar suas fotografias. Ele busca aquele instantâneo particular que satisfará seus objetivos - pois montar as fotografias de outrem não preencheria suas necessidades. Por isso, 0 artista a bandona uma montagem artística de fra gmentos fotográficos em prol da própria tomada peculiar da realidade ${ }^{36}$.

Fotomontagem e política: Klutsis

Rodtchenko não é o único artista a voltar-se para esse novo vetor da fo to montagem, que dá preferência à combinação de imagens integra is para compor uma narrativa politicamente engajada. Também El Lissitzki, que se aproxima da fotografia a partir de experiências com a fotomontagem ${ }^{37}$, propõe em 1926 "uma nova forma estética" para a nova linguagem, "claramente 
38. Apud BUCHLOH 1984, p. 102

39. BUCHLOH, 1984 p. 104-106

40. Apud BOIS, 1988 p. 166 determinada em termos sociais". Ao defender o uso de "fotografias acabadas, integrais" como elementos a partir dos qua is é possível construir "uma to talidade", o artista não só propugna a existência de "leis de formação" específicas para a fotomontagem, como estabelece uma relação intrínseca entre ela e 0 público de massa forjado pela Revolução de 1917 . Por isso, não hesita em reportar as experiências dadaístas ao âmbito estritamente artístico, abrindo uma única exceção para a Alemanha, em cujas produções reconhece a presença de "objetivos políticos"

Essa concepção de fotomontagem, na qual os elementos icônicos adquirem uma importância decisiva, tem um exemplo paradigmático no fo toafresco A tarefa da imprensa é a educação das massas (1928). Concebido para o Pavilhão Soviético da Exposição Internacional da Imprensa e da Editoria (C olônia, 1928), o fotoafresco, realizado com a colaboração de Sergei Senkin, é formado por uma compilação de imagens dispostas numa grade irregular. 0 efeito do conjunto é altamente dinâmico, uma vez que Lissitzki e Senkin justapõem em alternância diferentes ângulos de visão, close-ups e tomadas longas, proporcionando uma imagem cinemática das realizações soviéticas no campo do jornalismo e da editoria ${ }^{39}$ (Figura 4).

Em seus trabalhos Rodtchenko e Lissitzi demonstram, de maneira inequívoca, que a arte deve ser concebida como propaganda, isto é, como tomada de posição e a linha mento com as exigências do momento histórico. Lissitki já havia deixado isso bem claro na conferência sobre arte russa, proferida em Berlim e Amsterdã em 1922. A Revolução de 0 utubro havia confrontado os artistas com uma questão fundamental: "que papel desempenha a arte na nova sociedade, na qual o campo da atividade criadora se torna propriedade comum?" ${ }^{40}$. A resposta dada por ambos os artistas não deixa dúvidas sobre sua adesã 0 às exigências do momento histórico: a opção pela imagem fotográfica é uma maneira de satisfazer as necessidades de um público de massa, em grande parte semi-analfabeto.

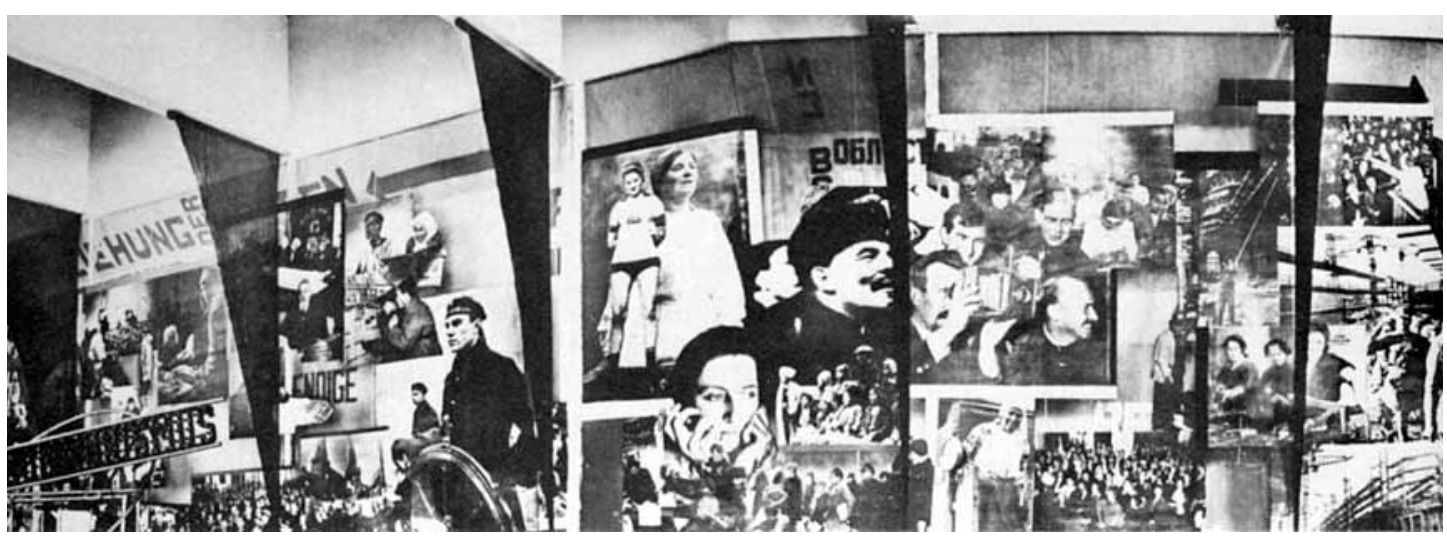

Figura 4: Lissitki e Senkin, A tarefa da imprensa é a educação das massas, 1928 (ADES, 1986, p. 64). 
$\mathrm{N}$ a década de 1920, a adesão mais evidente à propaganda é, sem dúvida, a de Klutsis, que se dedica à produção de cartazes políticos de derivação fotográfica. Como lembra Margarita Tupitsyn, desde A eletrificação de todo 0 país, 0 a rtista estava preocupa do com a relação visual entre o líder revolucionário e as massas. Ao primeiro líder, Lenin, a lém das produções já a na lisadas, Klutsis dedica uma série de fotomontagens em 1924, apresentando-o como uma força inspiradora a a nimar diferentes atividades sociais. Essa exaltação da figura individual sofrerá uma transformação a partir de 1928, quando é lançado 0 Primeiro Plano Q üinqüenal: nesse momento entra em cena um herói coletivo, as massas soviética $s^{41}$.

M esmo a o representar o novo ator social, Klutsis não deixa de lado os pressupostos construtivistas de suas primeiras fotomontagens, sobretudo 0 recurso à diagonal. Em $A$ realização nos transportes do Primeiro Pla no Q üinqüenal (1929), a combinação de elementos icônicos e visuais, dispostos em diagonal, confere um aspecto dinâmico ao conjunto, enfatizando o esforço industrializador empreendido pelo país (Figura 5). 0 mesmo recurso é utilizado em Pagaremos a dívida do carvão do nosso país (1930), no qual as diagonais formadas pelas pernas das três figuras de minera dores em movimento emprestam à imagem uma idéia de dinamismo e coesão; e no projeto de Trabalhadores e trabalhadoras, to dos à eleição dos Sovietes (1930), para o qual o artista concebe uma diagonal em progressão, a partir dos diferentes tamanhos das mãos espalmadas. A ela contrapõe-se uma outra diagonal, formada porimagens de uma multidão de mãos erguidas, de maneira a enfatizar a importância política do evento e 0 papel da coletividade ${ }^{42}$. Klutsis adota uma solução semelhante em Vamos realizar o plano das grandes obras (1930), no qual a uma grande mão espalmada se sucedem mãos de diferentes tamanhos e cenas de trabalhadores formando uma única diagonal. N esse cartaz, destinado à divulgação do Primeiro Plano Q üinqüenal, a mão reveste-se de um significado global: a adesão dos trabalhadores ao projeto governamental desdobra-se na representação do principal instrumento e símbolo do trabalho.

As fotomontagens políticas da década de 1930 passam por um processo de "normalização". Klutsis abranda o uso da diagonal em prol de uma composição baseada na simetria, como demonstra A luta pelo aquecimento e pelo metal (1933), dedicada à mineração. Para esse cartaz, o artista concebe uma estrutura vertical dominada pelas figuras de dois mineradores. 0 resultado da mineração - o pleno funcionamento da produção industrial e do sistema de transportes - integra-se harmoniosamente com as duas figuras gigantescas, gerando uma imagem equilibrada, para a qual contribui também o empuxo vertical das chaminés das fábricas, simetricamente dispostas.

0 uso da diagonal não é abandonado de todo. Q uando ela aparece, no entanto, não desempenha ma is uma função dinâmica. Em A luta pela colheita bolchevista é a luta pelo Socialismo (1931), as duas diagonais formadas pelo campo geram linhas de fuga que projetam o espaço da composição a o infinito. Em A realidade do nosso programa é o povo verdadeiro, somos você e eu (1931), a disposição dos grupos e dos ca ra cteres g rá ficos a presenta uma direção
41. TUPITSYN, 1991, p. 45.

42. Este cartaz recebe avaliações bastante antagônicas. Considerado, de um lado,"o melhor de todos os cartazes eleitorais" por sua "força expressiva" e "atualidade política", é criticado, de outro, por representar apenas o processo eleitoral, deixando de lado a dimensão do trabalho. Cf. LODDER, 1987, p. 190; TUPITSYN, 1991, p. 45. 


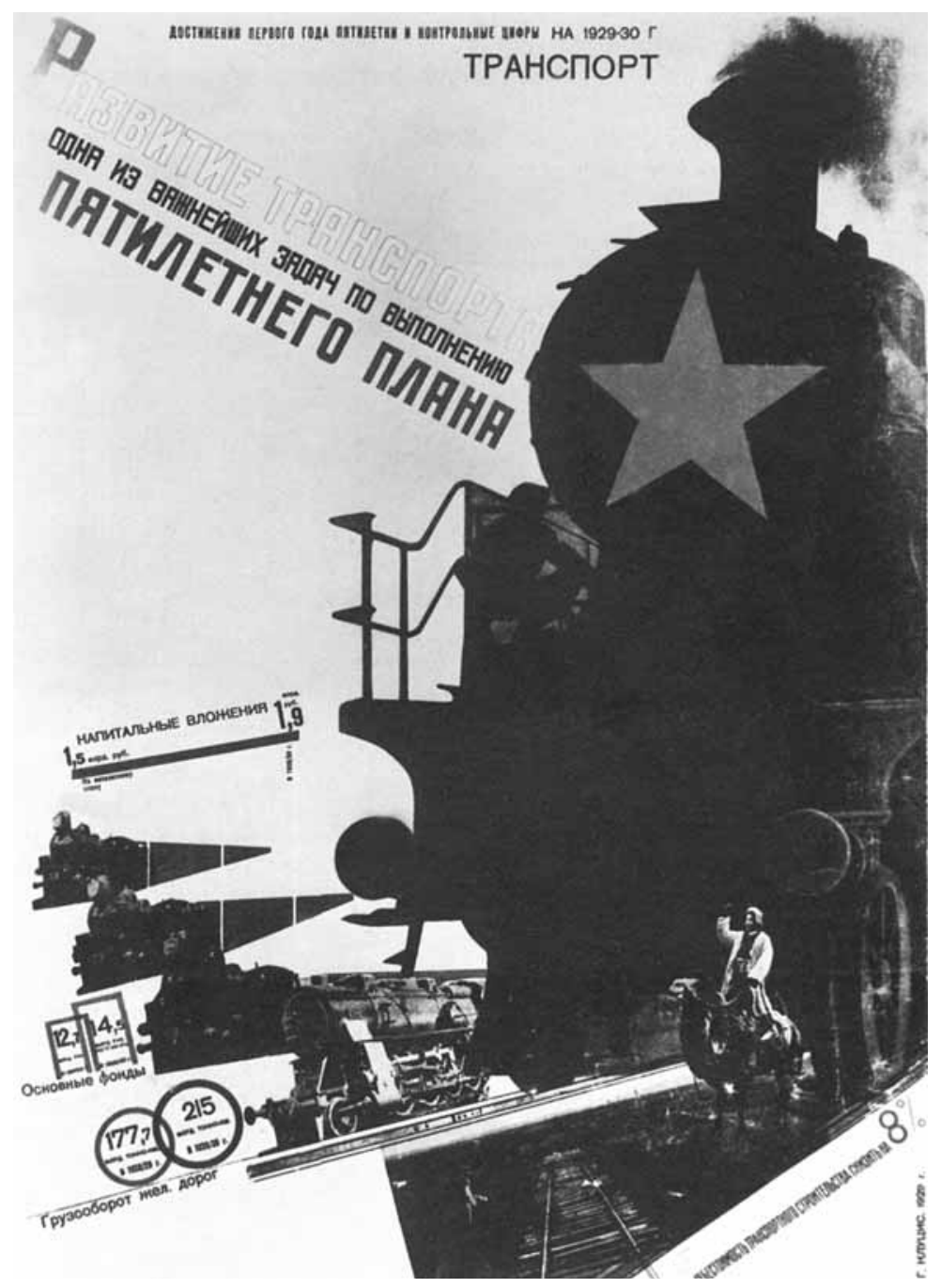

Figura 5 - Gustav Klutsis, A realização nos transportes do Primeiro Plano Q üinqüenal, 1929 (ADES, 1986, p. 77).

diagonal, sem que isso perturbe o equilíbrio do conjunto e 0 ritmo coeso do avanço dos trabalhadores capitaneados por Stalin.

0 novo líder político torna-se o protagonista absoluto dos cartazes realizados por Klutsis na década de 1930 , levando-0 a buscar a relação visual correta entre ele e as massas. Stalin, em geral, sobressai da multidão, a o ganhar uma dimensão monumental, que contribui para a mitologização de sua figura e da realidade do país. M esmo a relação com outros membros do Partido C omunista é regida pela monumentalidade da escala: numa fotomontagem realizada para o jornal Pravda (1935), a imagem de Stalin impõe-se sobre um retrato de Lenin, situado em segundo plano. A pose confiante assumida por ele é reforçada pelo 
uso de imagens que remetem ao poderio do país (fábricas, colheitadeiras, aviões e dirigíveis) e à satisfação de seu povo ${ }^{43}$.

0 culto de Stalin é paralelo a o poder autocrático exercido por ele no momento em que a União Soviética opta por uma política industrial baseada nos planos qüinqüenais, com a conseqüente primazia da indústria pesada e de bens de produção, e pela coletivização forçada da economia agrária. 0 planejamento industrial não responde apenas à necessidade de modernizar o país e de estabelecer relações de propriedade socialistas a fim de fazer frente à diferenciação social que ainda imperava no campo. 0 avanço do Fascismo na Europa C entral e, sobretudo, a ascensão do $\mathrm{N}$ azismo na Alemanha faziam aumentar o perigo de uma guerra de agressão contra a Rússia, o que motiva a urgência de constituir uma indústria bélica nacional.

A defesa do país passava também pelo aniquilamento da base econômica dos kulaks, que haviam se apropriado de grandes latifúndios durante a Revolução de 1917, sujeitando os camponeses mais pobres. 0 s kulaks - e mesmo os camponeses médios - eram considerados perigosos porque se temia que pudessem tornar-se aliados de uma intervenção anticomunista vinda do estrangeiro, a fim de defender seus interesses econômicos.

Longe da imagem de união e felicidade divulgada pela propaganda oficial, a sociedade soviética vivia um momento particularmente difícil: 0 nível de vida do operariado industrial havia piorado em virtude do escasso desenvolvimento da indústria de bens de consumo; a aplicação violenta da coletivização forçada no campo teve como conseqüências uma drástica redução da produção agrícola e a oposição à política governamental de quase todos os camponeses, inclusive aqueles das camadas inferiores.

A técnica da manipulação torna-se difusa, pois o Partido Comunista da União Soviética não tolerava debates internos, nos quais poderiam vir à tona os contrastes existentes no interior da sociedade e, muito menos, que tais controvérsias chega ssem à o pinião pública. Por isso, em 1933-1934 é suprimida a democracia interna, com a transformação da doutrina leninista do "centralismo democrático" na doutrina stalinista do "caráter monolítico do partido"44.

Para assegurar que as obras de arte responderiam aos requisitos de legibililidade e comunicação direta com as massas, o Estado, que era o único intermediário entre os artistas e o público, passa a exercer um contro le rigoroso sobre a produção cultural. 0 s planos qüinqüena is necessitavam de um apoio propagandístico para poderem firma r-se junto à opinião pública, razão pela qual não poderiam ma is ser permitidas todas as divergências entre a rtistas e intelectua is que haviam pontuado a década de 1920 . Requeria-se, a o contrário, a convergência de todos os esforços para operações que trouxessem um apoio concreto à linha do partido. Por isso, em 1932, é promulgado um decreto oficial que põe fim a todos os grupos artísticos e literários, prevendo sua reorganização em diversas federações centra is, de acordo com a própria especialidade. $\mathrm{N} 0$ caso das artes plásticas, é fundado o Sindicato dos Artistas C riadores. A par disso, o partido passa a exercer um controle crescente sobre os estilos e os temas
43. TUPITSYN, 1991, p. 47.

44. HOFMANN, 1971, p. 209-211. 
45. NEGRI, 1989, p.154155; EGBERT, 1973, p.83 84.

46. EGBERT, 1973, p. 59. das obras de arte, a fim de garantir a eficácia propagandística de quadros e cartazes ${ }^{45}$.

$N$ esse contexto, os cartazes realizados por Klutsis na década de 1930 podem ser vistos como peças de propaganda muito eficazes: ocultam as tensões que a gitavam a União Soviética por trás da imagem de uma sociedade unida num esforço comum, sob a segura liderança de Stalin. Bastaria lembrar a serena ordenação geométrica de A luta pela colheita bolchevista é a luta pelo Socialismo, graças à qual as diversas colheitadeiras dão a idéia de um trabalho harmônico e coordenado. A organização dada à imagem não pode ser dissociada da importância que o tema da coletiviza ção a dquire na arte soviética. os novos camponeses, em virtude do uso das máquinas agrícolas, eram considerados pela ideologia stalinista como parte integrante do processo de industria lização, isto é, do processo que tendia para o desenvolvimento do ponto de vista da classe proletária ${ }^{46}$.

0 utros exemplos de eficácia propagandística podem ser localizados na visualização de uma comunidade coesa, empenhada numa tarefa comum, própria de Trabalhadores e trabalhadoras, todos à eleição dos Sovietes e de $A$ realidade do nosso programa é o povo verdadeiro, somos você e eu. 0 u na exaltação da industrialização de A luta pelo aquecimento e pelo metal, na qual as duas figuras de trabalhadores desempenham o papel do homem novo necessá rio à construção do Socialismo, do herói sólido e positivo, firmemente engajado no devir da sociedade.

União Soviética em C onstrução (USSR na stroike)

0 trabalho de propaganda do regime é também confiado a publicações, entre as qua is a revista USSR na stroike (1930-1941), destinada a difundir uma imagem favorá vel do país no estrangeiro. Publicada em alemão, inglês, francês e espanhol, a revista é também difundida na União Soviética, pois promovia uma visão otimista do Primeiro Plano Q üinqüenal. Inspirada no exemplo das revistas ilustradas alemãs da década de 1920 e da AIZ, USSR na stroike pretende "refletir na fotografia o objetivo geral e a variedade do trabalho de construção que está ocorrendo na URSS". A preferência pela imagem técnica responde a uma razão precisa. A fotografia é escolhida como "um método para ilustrar a construção socialista", uma vez que ela "em muitos casos, fala de uma maneira muito mais convincente que o artigo escrito do modo mais brilhante". De acordo com essa premissa, a revista conta com a colaboração dos principa is fo tojo rna listas do períod o - entre os qua is A bram Shterenberg, que ha via rea liza do as fotografias de Sobre isso - e de artista s como El e Sophie lissitki, Rodtchenko e Varvara Stepanova. Também John Heartfield, que realizava fotomontagens para $A I Z$, órgão do Partido C omunista Alemão, colabora com USSR na stroike. Q uando visita Moscou em 1931, elabora uma fotografia composta de Lenin, na qual o líder se sobrepõe a uma vista aérea da cidade (no número de setembro), 
concebe o layout e a capa do número de dezembro, dedicado à indústria do petróleo, e publica também a conferência sobre fotomontagem, proferida no Instituto Poligráfico da capital47.

A presença de Lissitzki e Rodtchenko é determinante para imprimir uma nova feição visual à revista. A té outubro de 1932, ela tinha uma estrutura bastante simples: era ainda praticamente uma seqüência de imagens a companhadas de textos explicativos. A o projetar o número de outubro de 1932 , dedicado à usina hidrelétrica e à represa do Rio Dnieper, Lissitzi concebe-o como uma narrativa visual na qual lança mão das técnicas da arte moderna e da tipografia: letras arrojadas, fotomontagens, cores fortes, entre outras $s^{48}$.

0 mito do líder político é a nota dominante da narrativa elaborada por Lissitzki. Lenin é evocado inicialmente pelo lema que estivera na base do cartaz de Klutsis de 1920 ("C omunismo é governo dos Sovietes + eletrificação de todo o país." V. I. Lenin) (Figura 6). 0 programa de eletrificação do país é apresentado em seu estágio final graças à fotografia de duas mãos gigantescas empenhadas na abertura das comportas da represa. Desse modo, o a rista cria um elo simbólico entre a ideologia da industrialização e a participação dos

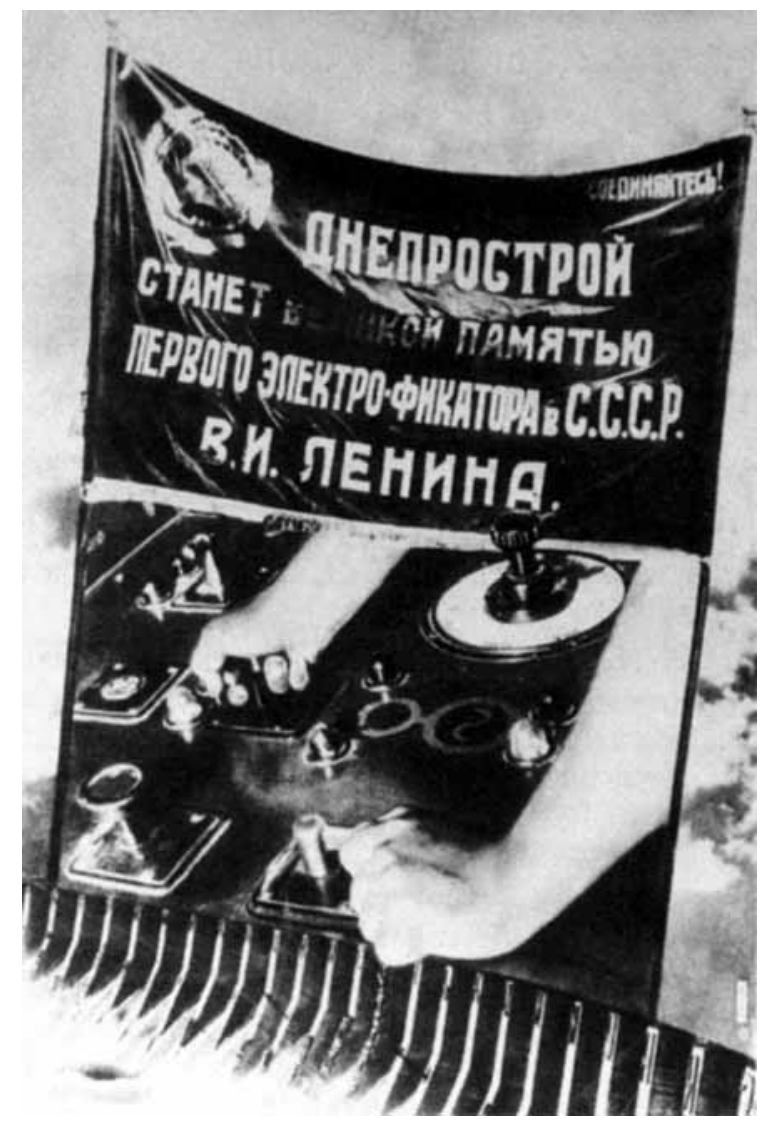

Figura 6 - Lissitzki, Comunismo é governo dos Sovietes + eletrificação de todo o país, 1932 (M ARG 0 LIN , 1997, p.173).
47. MARGOLIN, 1997 , p. 166-171.

48. Id., p. 171-172. 
49. MARGOLIN, 1997, p. 175. trabalhadores na construção do futuro do país, recorrendo a uma imagem muito empregada na iconografia da esquerda - a mão produtora e configuradora de um novo mundo.

A imagem de Lenin está presente em mais duas fotomontagens. $\mathrm{N}$ a primeira, Uma conversa entre dois mundos, Lissizki propõe um contraponto entre a concretização do projeto do líder, tipificada pela presença de um trecho da rede elétrica surgida com o empreendimento do Dnieper, e a visão negativa do escritor H. G. W ells, que colocara em dúvida a capacidade da Rússia levar adiante uma iniciativa tão a mbiciosa. Victor $\mathrm{M}$ argolin chama a tenção para os recursos utilizados pelo artista para criar o contraste: diferença de escala entre W ells e Lenin, presença de uma página de Russia in the shadows em formato gigantesco nas mãos do escritor e contraposição entre um vilarejo do passado e a rede elétrica que se destaca num céu cheio de nuvens, símbolo das potencialidades ilimitadas do país ${ }^{49}$ (Figura 7 ).

$\mathrm{N}$ a segunda fotomontagem, VIII Congresso dos Sovietes, Lissitzki sobrepõe a imagem de Lenin discursando no encontro de 1920, durante o qual apresentara seu plano para a eletrificação do país, a um mapa da Rússia. N este é destacado o lugar de construção da represa e da hidrelétrica. Uma flecha pontilhada atravessa o mapa para indicar as águas do rio que seriam represadas. A fotografia de Lenin escolhida pelo artista é bem significativa: o líder parece

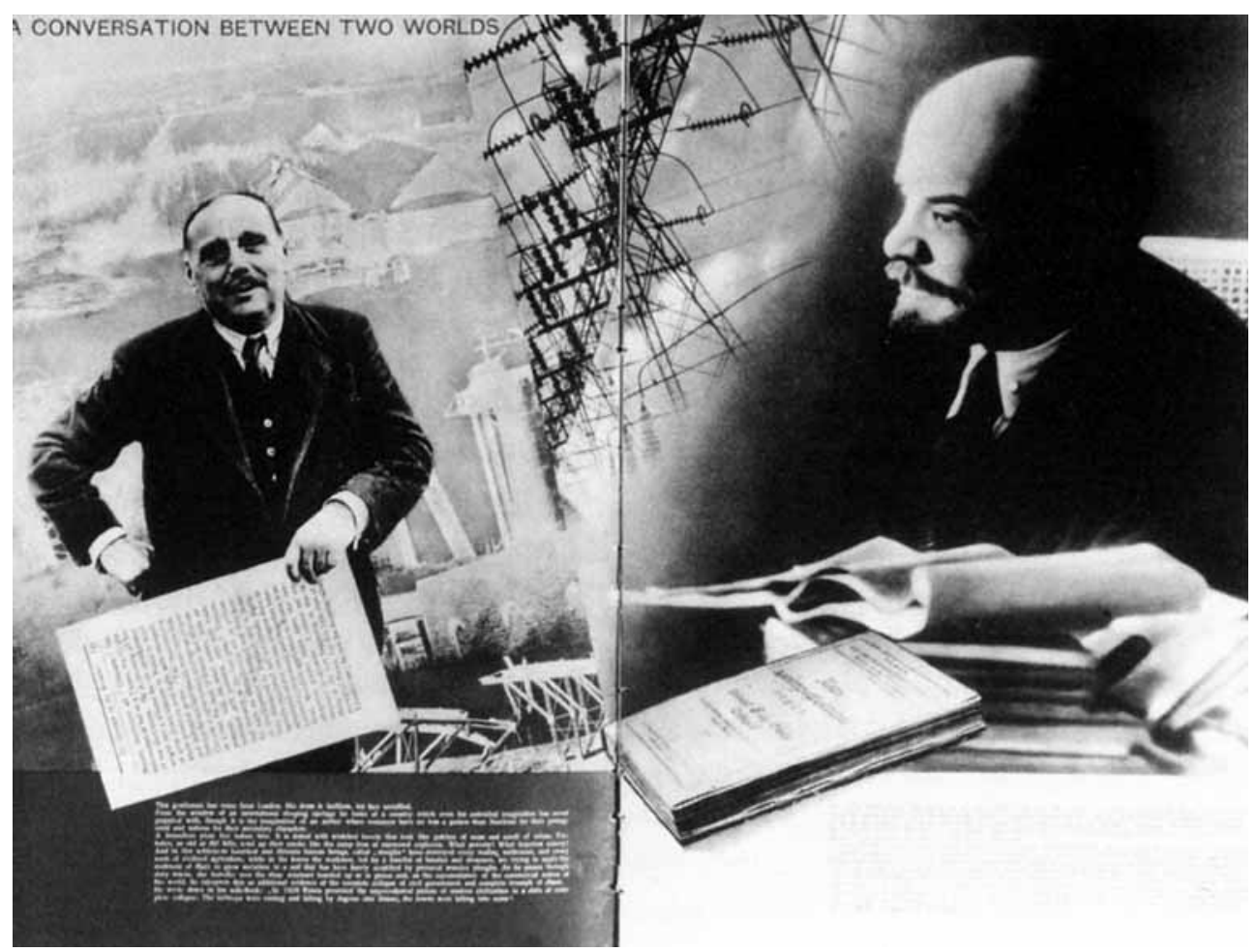

Figura 7 - Lissitki, Uma conversa entre dois mundos, 1932 (M ARG 0 LIN , 1997, p.176). 
estar olhando para a futura realização de seu projeto, havendo uma correspondência entre a direção de seu olhar e a flecha que atravessa o mapa.

Se Lenin é a figura dominante do conjunto do Dnieper, Lissitzki não poderia deixar de lembrar Stalin, que transformara em realidade o projeto do primeiro. A fotomontagem A corrente é ligada associa a imagem de Stalin a uma mão gigantesca que aciona o dispositivo da hidrelétrica e à usina iluminada. Um feixe de raios diagonais que se irradia de diversos pontos da hidrelétrica cria uma conexão entre a mão do trabalhador e a efígie de Stalin numa retomada do dispositivo simbólico que estivera na base da primeira composição do conjunto.

Em outras fotomontagens dedicadas à usina, Lissitki coloca em cena a capacidade soviética de concretiza r um projeto utópico e sua rela ção intrínseca com a construção do Socialismo. Em Projeto da construção do Dnieper Construção do Dnieper concluída, a estratégia visual articula -se em quatro momentos: a apresentação do projeto pelo engenheiro Krzkizkanoski, à qual se sobrepõe a imagem dos apontamentos que serviram de base à sua elaboração; o estudo dos desenhos por uma comissão; a maquete da represa e a represa em funcionamento. Para onde vai a corrente funciona como a conseqüência lógica do empreendimento: a rede elétrica espalha-se para os quatro pontos cardeais, nos quais são destacados estabelecimentos industria is que se beneficiaram da usina ${ }^{50}$.

0 conjunto finaliza-se numa imagem que enfeixa simbolicamente 0 significado da eletrificação da União Soviética (Bolcheviques). Lissitzki conjuga no mesmo espaço a imagem de uma manifestação política com a de diversas to rres de energia para criar um efeito de correspondência entre o povo e as realizações do regime. 0 efeito é reforçado pela presença de uma grande faixa horizontal que une os dois planos com o dizer "Bolcheviques"; graças a ela 0 artista confere um ulterior significado ao povo soviético, que é visto também como beneficiário de um empreendimento tão grandioso (Figura 8 ).

Embora os elementos icônicos tenham o predomínio nesse conjunto de fotomontagens, elas se caracterizam também pelo emprego de alguns recursos visuais que remetem à poética do Construtivismo: uso de diagonais ( $A$ corrente é ligada e a capa da revista URSS na stroike, que utiliza a mesma imagem da usina), do círculo como elemento integrador (Para onde vai a corrente), da flecha como metáfora do progresso (VIII Congresso dos Sovietes), da horizontal como plano que estrutura a composição reforçando sua frontalidade (Bolcheviques).

A colaboração de lissitki a USSR na stroike é bastante intensa depois de 1932 e abarca diversas temáticas: 0150 a niversário do Exército Vermelho (fevereiro de 1933), a conquista do Ártico (setembro de 1933), 015 o aniversário da indústria petrolífera do Azerbaijão (maio de 1935), 015 o a niversário da Geórgia soviética (abril-maio de 1936), a região autônoma de KabardinoBalkarian (outubro de 1936), o povo do território de 0 rjonikidze (março de 1937 ), a Constituição de Stalin (setembro-dezembro de 1937 ), Ucrânia ocidental e Bielo-Rússia ocidental (fevereiro-março de 1940).
50. MARGOLIN， 1997 p. 175-178. 
51. BUCHLOH, 1984

p. 114

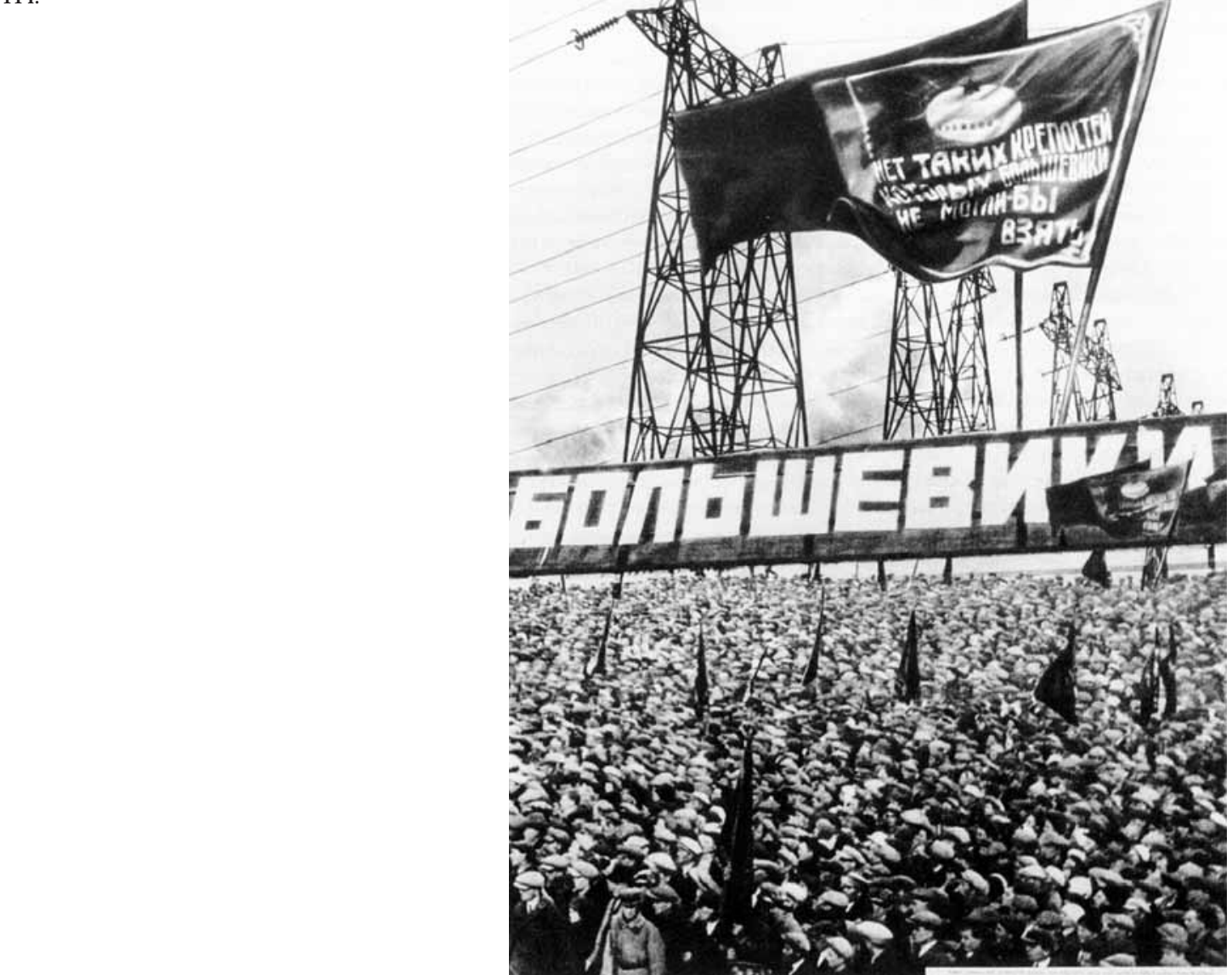

Figura 8 - Lissitki, Bolcheviques, 1932 (M ARG 0 LN , 1997, p.179).

A a valiação dessa faceta de Lissitzki é bastante controvertida na historiografia artística. Benjamin Buchloh utiliza o termo "distorção" para a postura daqueles historiadores que detectam no envolvimento de Lissitzki e Rodtchenko em USSR na stroike um sacrifício em relação a o momento abstrato. 0 autor, a o contrário, advoga uma precisa identidade política para os dois artistas, pois considera sincero e entusiasta seu engajamento na causa stalinista. Sua atitude, aliás, é fundamental para o entendimento de um dos mais profundos conflitos da arte moderna: a dialética histórica entre a autonomia individual e a representação de uma coletividade por intermédio de sínteses visuais ${ }^{51}$.

Essa visão positiva do engajamento de Lissitzki no aparelho de propaganda do Estado não é compartilhada por Yve-Alain Bois. Em desacordo com a hipótese de Buchloh, que a tribui o novo rumo tomado pelos artistas de vanguarda desde a década de 1920 não só a uma crise da representação, mas também a uma redefinição da relação da produção artística com o público de massa, Bois qualifica o trabalho de propaganda de lissitki como a tentativa 
de transformar "a a rte num mero instrumento, isto é, num artefa to não crítico, a serviço do poder constituído"52.

Victor M argolin, por sua vez, não concorda com esse argumento, pois acredita que lissibki criou um novo estilo narrativo, capaz de satisfazer os objetivos retóricos dos editores de USSR na stroike. 0 que M argolin entende por novo estilo narrativo pode ser inferido de sua a nálise do trabalho dedicado à conquista do Ártico:

Lissitzi estava se tornando perito em combinar logotipos e patos, informação e emoção em seus layouts. Usando contrastes de escala, mapas, fotomontagens e amplos desdobramentos fotográficos, era capaz de descrever a história da expedição ao Ártico com inúmeros detalhes, sem deixar de infundir um senso do extraordinário no ordinário, que caracterizava um dos aspectos da produção artística soviética nos anos $30^{53}$.

0 novo estilo narrativo, tipifica do pelas primeiras colaborações com a revista, transforma-se em "narrativa épica" em mea dos dos anos 1930, quando Lssitzi se afasta das experiências de vanguarda. Segundo M argolin, esse novo momento

era caracterizado por seu alcance histórico e pelo modo com que juntava grandes quantidades de informação visual - sobretudo fotografias, fotomontagens, desenhos, pinturas e mapas numa estrutura coerente. Era também caracterizado por expedientes visuais ta is como emblemas heráldicos, bandeiras e outras insíg nias que davam dignidade ou nobreza ao tema. Esse estilo era caracterizado igualmente por um senso de fluxo visual, capaz de transmitir a diversidade de uma região e destacar, a o mesmo tempo, imagens e acontecimentos icônicos singulares como metáforas que a caracterizavam ${ }^{54}$.

Um exemplo paradigmático dessa nova direção pode ser localizado no número dedicado à Constituição de Stalin, no qual Lissitzki, a uxiliado pela esposa Sophie, trabalha com materiais de arquivo, fotografias documentais, desenhos, gráficos e mapas. Para a página de rosto, é concebida uma fo to montagem que deveria simbolizar a superiorida de da vida na União Soviética (O perário e camponesa de uma fazenda coletiva). Por isso, El e Sophie Lissitzi colocam no topo de um globo terrestre - no qual o contorno da União Soviética é delineado em vermelho - a escultura 0 perário e camponesa de uma fazenda coletiva, de Vera Mukhina, realizada para servir de coroamento a o Pavilhão Soviético na Exposição Universal de Paris de 1937.

A escolha dessa obra para simbolizar a vida na União Soviética de Stalin é bem significativa em termos ideológicos. 0 grupo escultórico nã o só respondia aos ditames do Realismo socialista, que postula va que uma obra de arte deveria ser socialmente útil, dinâmica e didática, como era também uma representação da estrutura social do país posterior ao Primeiro Plano Q üinqüenal. o operário e a camponesa que avançam juntos, levando o martelo da indústria e a foice da agricultura, simbolizam a convicção de Stalin de que o sucesso da mecanização da agricultura havia provocado uma convergência entre os interesses do operariado industrial e os do campesinato. Embora o operário
52. BUCHLOH, 1984, p. $94 ;$ BOIS, 1988, p. 175.

53. MARGOLIN, 1997, p. 183.

54. Id., p. 196. 
ainda liderasse o processo, os dois grupos caminhavam próximos, rumo à realização de uma sociedade sem classes, verdadeiramente comunista ${ }^{55}$.

Imagens da vida no país pontuam esse número especial de USSR na stroike. Em Artigo 12, um conjunto de fotografias, representando camponeses, militares, um operário, um cientista, um músico e um funcionário, tem por objetivo reconduzir a diversidade de tarefas socialmente úteis a um denominador comum que simboliza a união nacional. A presença de uma moldura formada por uma grinalda de folhas e bagas, além de fazer referência à fertilidade do solo, pode ser reportada a uma ma nifestação particula r do Realismo Socialista: a valorização da arte folclórica como criação coletiva, na qual se manifestavam a um só tempo valores locais e universa is ${ }^{56}$.

Em Artigo 126, os cidadãos da União Soviética comparecem como pano de fundo de uma representação glorificadora do papel do partido na vida do país: ser a vanguarda dos trabalhadores em sua luta pelo fortalecimento e desenvolvimento do sistema socialista. A diferença de escala entre os diversos representantes das repúblicas soviéticas, altos membros do partido e Stalin é bem significativa: a centralida de do líder não deriva a penas de sua colocação estra tég ica na fotomontagem, mas sobretudo do tamanho gigantesco que lhe é dado, graças ao qual sobrepuja as demais lideranças políticas (representadas num tamanho médio) e as cenas de multidão (às quais é reservado um formato pequeno).

Constituição stalinista, povo soviético feliz, que encerra a narrativa visual desse número, é uma peça retórica de grande eficácia, que só

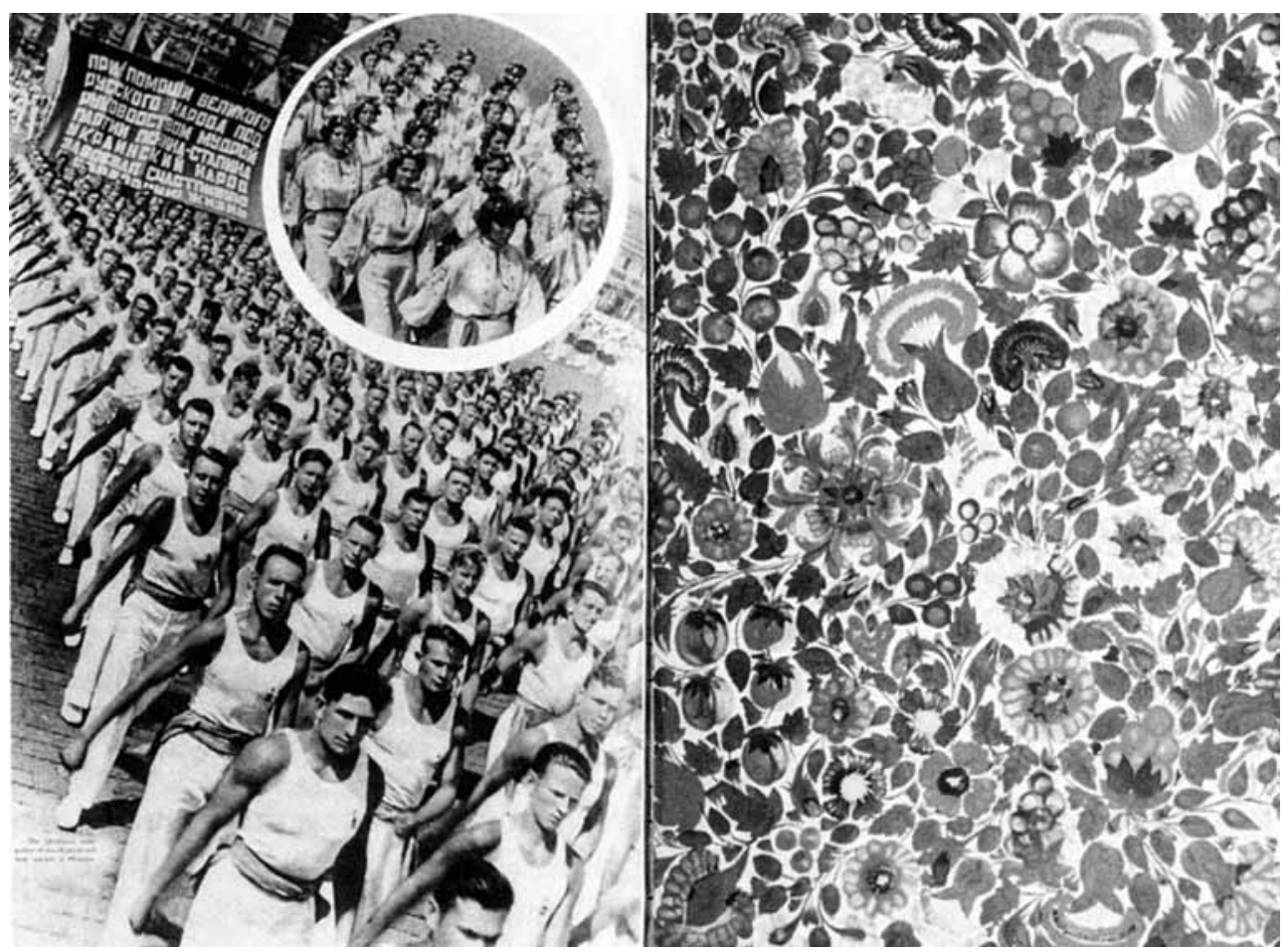

Figura 9 - Aleksandr Rodtchenko e Varvara Stepanova, Sem título, 1938 (M ARG 0 UN , 1997, p.208). 
aparentemente não coloca em cena o líder personalista. A justaposição de mães so rridentes carregando seus filhos, atletas desfraldando bandeiras e crianças exibindo buquês de flores, tendo como traço de união o emblema do Estado e os dizeres "Constituição stalinista, povo soviético feliz", tem seu significado reforçado por uma declaração de Stalin, que contrapõe à "barbárie fascista" a "assistência moral" e o "apoio real" que a nova Constituição do país poderia dara todos a queles que se opunham a o to ta litarismo (Figura 10 ). Essa decla ração visava não apenas ao público interno, mas sobretudo aos países estrangeiros nos quais USSR na stroike circulava. O clima político-social que imperava no fim dos anos 1930 - tensões internacionais, persistência da crise econômica desencadeada em 1929 e ascensão do Nazismo - era favorável a uma valorização geral da potência da União Soviética e à sua idealização pelos partidos integrantes da Internacional C omunista ${ }^{57}$.

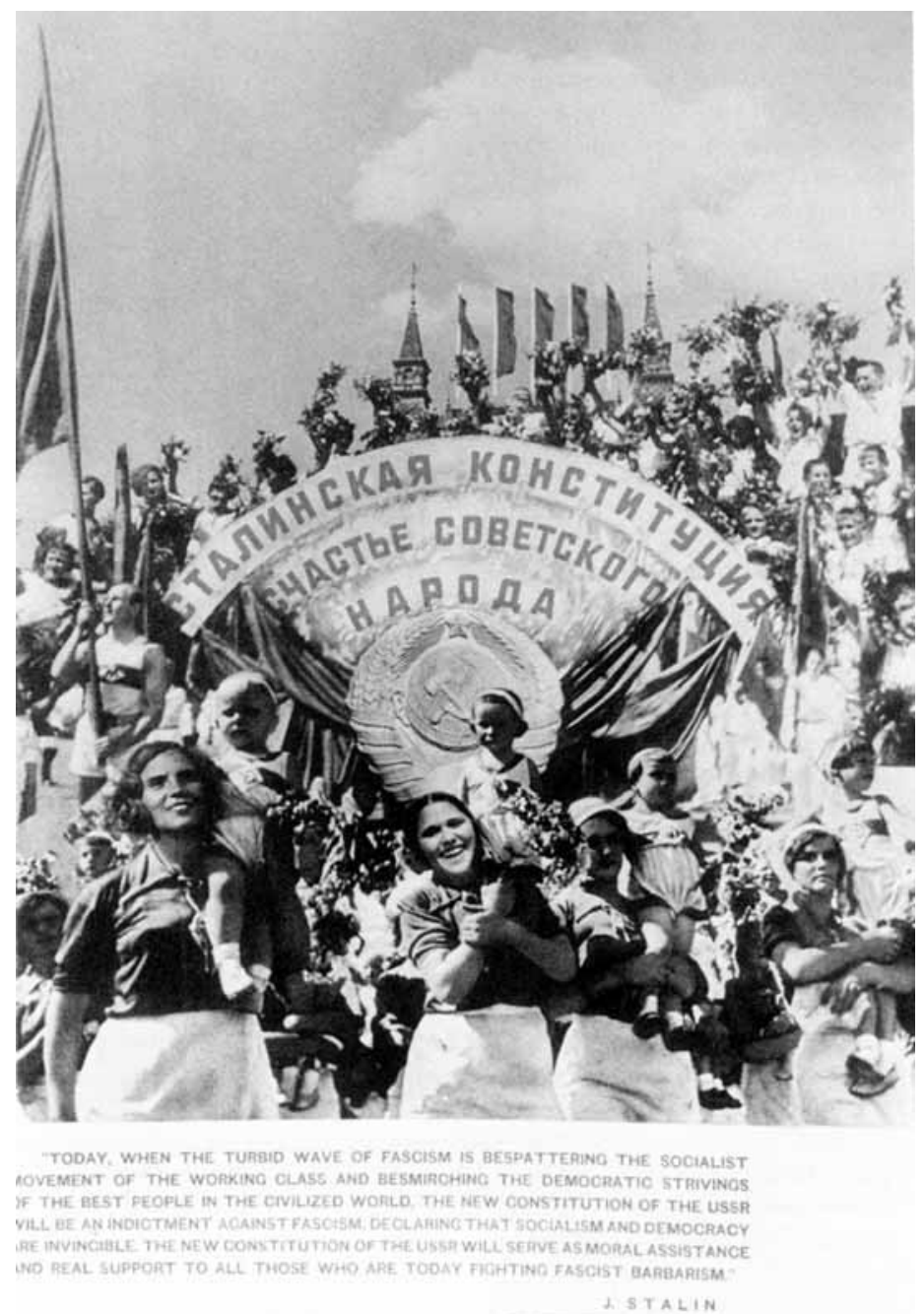

Figura 10 - El e Sophie Lissitzki, Constituição stalinista, povo soviético feliz, 1937 (M ARG O UN , 1997, p. 205).
57. HOFMANN, 1971 p. 216 
58. MARGOLIN, 1997 p. $199,204,206$.

59. Id., p. 183; PHILLIPS, 1995, p. 87-88.

60. Apud MARGOLIN 1997, p. 187. No mesmo ano, Rodtchenko publica o álbum A construção do Canal do Mar Branco. 0 tom épico da narrativa visual é confiado a imagens nas quais a documentação vem freqüentemente acompanhada de efeitos construtivistas, como o uso de diagonais e de estruturas geométricas, ora lineares, ora maciças.
Margolin considera esse número de USSR na stroike como o ápice do estilo na rrativo de Lissitzki, que vai de uma "adulação altamente emocional de Stalin às sóbrias a presentações de estatísticas industriais". Ao lembrar que essa edição, publicada no apogeu dos expurgos, tinha por objetivo desviar as a tenções internacionais deles, o autor mostra como Lissitzki cria uma narrativa comprometida com o governo, adaptando seu talento às necessidades retóricas do regime ${ }^{58}$.

Se bem que em escala menor, o mesmo pode ser dito de Rodtchenko, cuja colaboração à revista é também marcada, em alguns momentos, pela dissonância entre representação e realidade. Isso fica patente no número dedicado à construção do $\mathrm{C}$ anal do $\mathrm{M}$ ar Branco ( $\mathrm{C}$ anal Stalin), no Báltico, em dezembro de 1933. 0 artista realiza três viagens à região entre 1931 e 1933, cujo resultado são mais de duas mil fotografias que registravam a construção de um vasto sistema de eclusas e canais num espaço de tempo bem reduzido. $\mathrm{N}$ a configuração de uma épica moderna, na qual a conquista da natureza por parte da organização e da tenacidade do homem soviético é dra matizada, Rodtchenko não leva em conta os custos humanos do empreendimento. Uma vez que o orçamento destinado à obra era reduzido, recorre-se ao trabalho de presos de direito comum e políticos, que morrem aos milhares durante a construção do canal, um dos maiores projetos do Primeiro Plano $Q$ üinqüena ${ }^{59}$.

0 artista tem uma visão positiva do empreendimento, patente não apenas nas imagens que realiza, mas também num artigo publicado em 1936:

Era uma guerra entre 0 homem e a natureza selvagem. 0 homem veio e venceu, venceu e transformou-se. Tinha chegado abatido, castigado, a margurado e saiu de cabeça erguida, com uma medalha no peito e um passaporte para a vida. [...] Foto grafei de maneira simples, sem pensar no formalismo. Eu estava surpreso com a acuidade e a real sabedoria com as quais as pessoas estavam sendo reabilitadas ${ }^{60}$.

0 a taque à terra foi feito com enxadas e explosivos transmite essa impressã o em termos visuais. Rodtchenko mostra homens orgulhosos do próprio trabalho, engajados ativa mente numa série de tarefas necessárias à construção do canal: escavando com enxadas, levando materiais no carrinho de mão, usando furadeira e explosivos, construindo as comportas. 0 que 0 artista entende por "fotografar de maneira simples, sem pensar no formalismo" é evidenciado nessa imagem, em que são deixados de lado os diversos ângulos de visão e as to madas em diagonal, que caracterizavam a série dos Pioneiros (1928-1930) e o registro de manifestações patrióticas. Se o que está na base dessa composição é a mesma idéia de um ritmo coletivo, Rodtchenko, no entanto, não o representa a partir de uma estrutura geométrica ou de um ponto de vista inovador. Prefere confiar 0 impacto da imagem a uma iconicidade não alheia a certos aspectos pictóricos, evidentes sobretudo nas figuras do primeiro plano que, com suas roupas escuras, criam um contraste cromático com a paisagem nevada (Figura 11).

0 utras fotografias que integram o conjunto mostram, a o contrário, um Rodtchenko mais próximo dos pressupostos do Construtivismo fotográfico. É 0 caso de uma imagem tomada em diagonal, que confere uma inclinação 


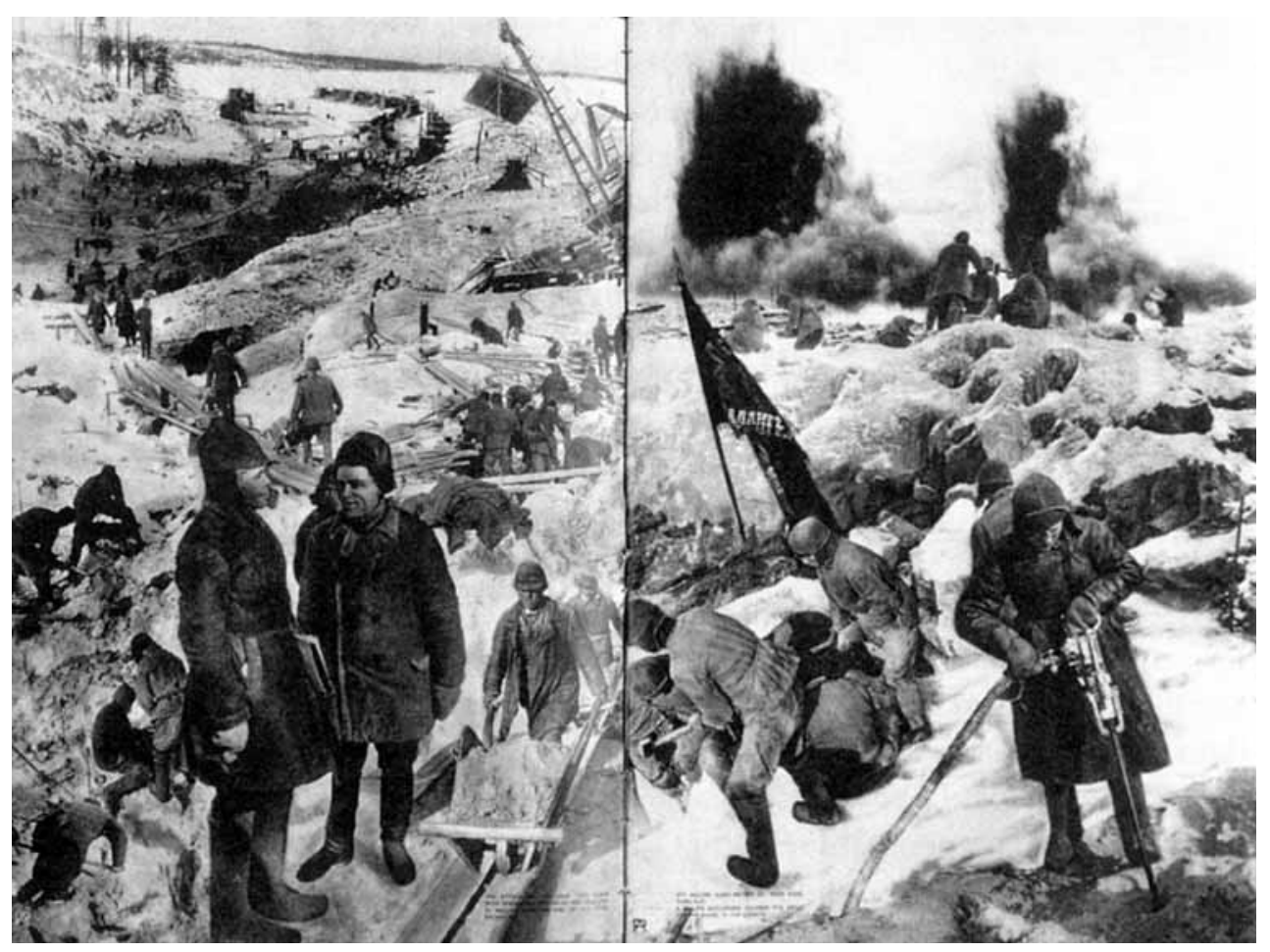

Figura 11 - Aleksandr Rodtchenko, 0 a taque à terra foi feito com enxadas e explosivos, 1933 (M ARG O UN , 1997, p.188).

acentuada à composição, gerando um efeito dinâmico. A metáfora do trabalho coletivo como equivalente à harmonia de uma orquestra é acentuada por dois recursos: a imagem de dois músicos em primeiro plano e a presença de um texto que faz referência à regeneração pelo trabalho de "ex-ladrões, bandidos, kulaks, salteadores, assassinos [que] pela primeira vez tornaram-se conscientes da poesia do trabalho, do romance da tarefa de construção. Trabalharam para a música de sua própria orquestra". É o caso ta mbém da maior parte das tomadas do canal, regidas por uma visão formalista, que dá primazia a formas puras e gigantescas para simbolizar a vitória do homem sobre a natureza.

Em outros trabalhos para a revista, nos qua is conta com a colaboração da esposa, Rodtchenko realiza algumas experiências visua is bem próximas de seu momento vanguardista. É o que acontece, por exemplo, no número de a gosto de 1936, dedicado à exportação de madeiramento. Em 0 madeiramento chega aos portos de todas as partes da União Soviética, Rodtchenko e Stepanova apresentam uma fotomontagem regida por dois registros: um realista (trem, navio e parte superior de um edifício oficial), outro abstrato (as pilhas de madeira). Este último evoca as diagonais dinâmicas que Rodtchenko havia usado no trabalho gráfico dos anos 1920, além de trazer a marca daqueles ângulos de visão não usuais que haviam caracterizado sua primeira fotografia (Figura 12 ). O s mesmos parâmetros podem ser encontra dos numa composição reproduzida 
61. Apud MARGOLIN 1997, p. 192 em página dupla, na qual se destaca, primeiramente, uma imagem de troncos cortados, em fileiras cerradas, formando um padrão geométrico. Em cima deles, Rodtchenko e Stepanova colocam um semicírculo com a fotografia de um navio. A segunda parte da composição representa pilhas de madeira que criam uma estrutura geométrica e linear, às qua is é sobreposta a imagem de uma serraria englobada num outro semicírculo. A fonte dessas imagens deve ser buscada no trabalho realizado por Rodtchenko com a equipe do documentário Exploração ind ustria I da madeira, que não chegou a ser concluído (1931). N a quela oca sião, 0 artista havia realizado uma série de fo to grafias que remetem aos postulados do Construtivismo fotográfico, pois se caracterizavam por tomadas em diagonal e por efeitos freqüentemente lineares e abstratos.

M últiplos ângulos de visão e uma sutil estruturaçã o geométrica conferem um aspecto dinâmico e, em certos momentos, abstra to à fotomontagem $A b$ rindo seus pára-quedas e cobrindo o céu com eles... (dezembro de 1935). A imagem de Stalin, que se destaca no interior de um círculo, olhando para o alto, deve ter sido provavelmente inserida por motivos editoriais a fim de reforçar a idéia do vigor do temperamento soviético. $\mathrm{N}$ a apresenta ção do número há, com efeito, um editorial que propõe um elo simbólico entre o pára-quedismo e "nosso empenho stalinista, nossa vontade de voar mais alto, nosso desejo de ampliar o horizonte da vida, de fazê-la mais brilhante, mais vasta e mais alegre" ${ }^{\prime 61}$.

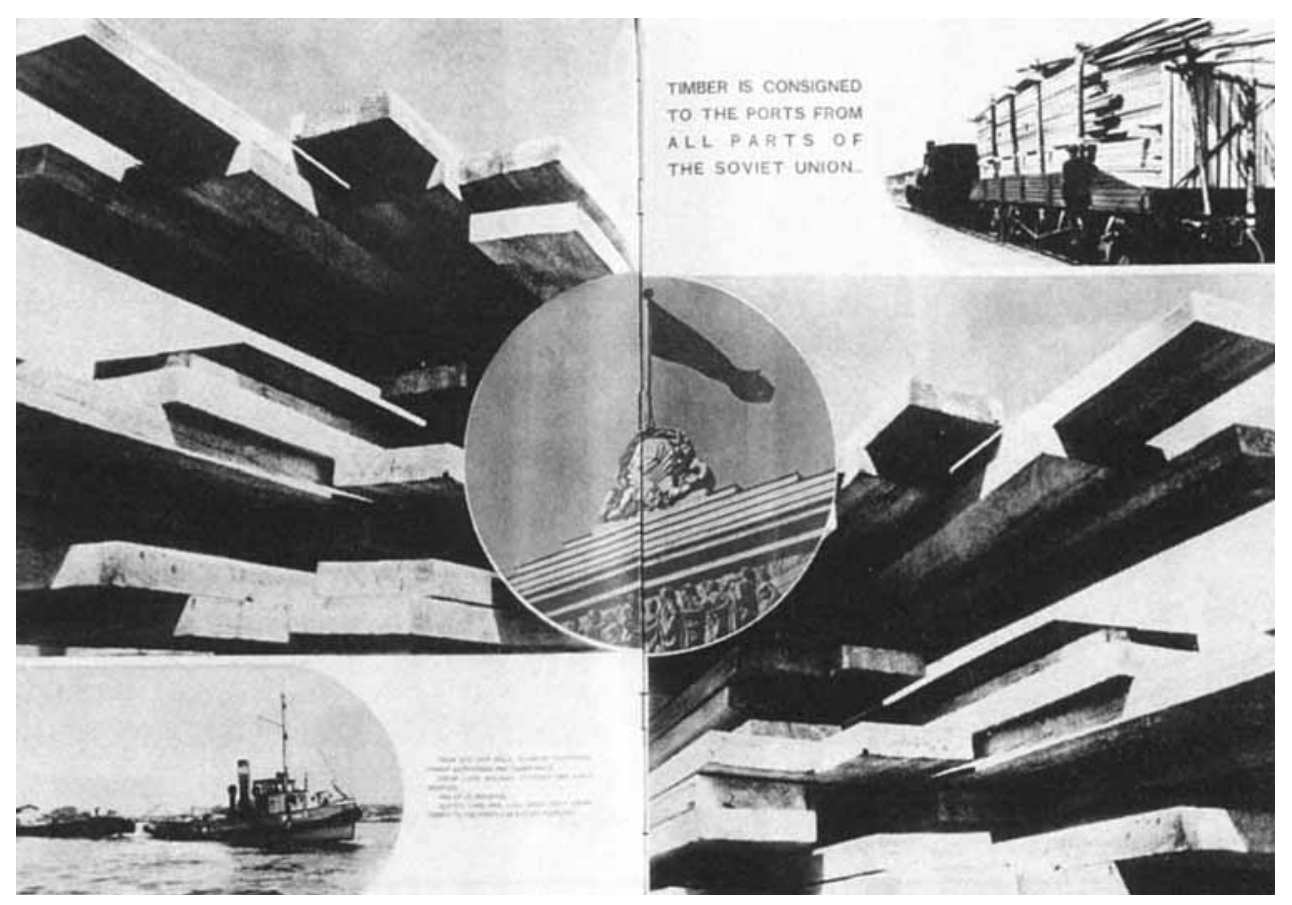

Figura 12 - Aleksandr Rodtchenko e Varvara Stepanova, 0 madeiramento chega a os portos de todas as partes da União Soviética, 1936 (M ARG 0 UN , 1997, p.194). 
0 engajamento de Klutsis, Rodtchenko e Lissitzki na causa da revolução é marcado por alguns dos postulados-chave da estética oficial: preocupação com o realismo, o didatismo, a clareza da mensagem e a utilidade social; figuração do herói positivo; inserção da tese no espaço da composição; escamoteio de todo conflito, entre outro ${ }^{62}$. Diante desse quadro de referências, o que cabe discutir não é o "sacrifício" que esses artistas fizeram para servir à razão política, mas a decisão por eles tomada de desenvolver novas ferramentas visua is para disseminar a mensagem revolucionária. M argarita Tupitsyn não tem dúvidas de que 0 uso de fotografias e fotomontagens num suporte como o cartaz foi a última grande experiência da vanguarda soviética, tendo conseguido a dapta r-se surp reendentemente às necessida des da propaganda visual de Sta lin ${ }^{63}$.

Se for analisado o engajamento político dos três artistas, a adaptação de suas linguagens à propaganda stalinista não parecerá, contudo, surpreendente. $\mathrm{N}$ o caso de Klutsis, é visível sua vontade de contribuir para a construção do mito do novo mundo e do papel desempenhado dentro dele pelo homem novo. A fotomontagem 0 velho mundo e o mundo que está sendo construído agora é exemplar nesse sentido, podendo ser analisada à luz do mito de origem. Se é próprio do mito de origem justificar uma situação nova, contando como o mundo foi modificado e enriquecido, a fotomontagem de 1920 enquadra-se em seus pressup ostos, po is oferece uma visualização eloqüente de dois períodos da história soviética, a fim de melhor enfatizar o momento inaugural instaurado a partir de 1917. A contraposição entre o mundo do passado, a niquilado pela revolução, e a criação do novo mundo, representada por Lenin, inscreve-se plenamente na ordem do mito, não só por ser a narrativa de uma "história verdadeira", isto é, de uma história que se refere à realidade, mas também por lançar mão de uma dicotomia simbólica, na qual o elemento icônico desempenha uma função primária em relação àquele conceitual ${ }^{64}$.

Um outro aspecto mítico permeia a produção de Klutsis: a representação do herói nacional como modelo exemplar de vida e de comportamento ${ }^{65}$. É nessa dimensão que parece residir o elo entre o Klutsis engajado na vanguarda e o Klutsis propagandista de Stalin. Lenin e Stalin são alçados, de fa to, a uma condição heróica, por terem salvado o povo da opressã o e $d a$ fome, oferecendo-the um presente sereno e livre de tensões e um futuro brilhante. 0 Lenin de A eletrificação de to do o país e o Stalin de A realidade do nosso programa é o povo verdadeiro, somos você e eu, por exemplo, podem ser vistos como paradigmas dessa visão heróica pelas dimensões que lhes são dadas, ou pela simbologia de que vêm carregados: com um signo do progresso nas mãos, o primeiro; chefiando a marcha triunfal dos trabalhadores, o segundo.

Essa mesma dimensão heróica, pela qual a figura do líder emblema as conquistas sociais, enforma o trabalho de Lissitzki para o número de USSR na stroike dedicado ao empreendimento do Dnieper. $N$ esse, aliás, é também mobilizado o mito de origem, uma vez que Uma conversa entre dois mundos
63. TUPITSYN, 1991, p. 47

64.A respeito do mito ver ELIADE, 1975, p. 9,11,15 16, 33; DORFLES,1965, p. 49-50.

65. ELIADE, 1975, p. 18. 
66. BARTHES, 1970, p. $230-231$.

67. TUPITSYN, 1991, p. $41,47$.

68. DICKERMAN, 2000 p. 142 pode ser vista como uma contraposição entre a cegueira do passado (W ells) e a capacidade de escancarar o futuro graças a um gesto inaugural (Lenin).

Rodtchenko não está a salvo dos efeitos da mitologização da vida soviética, como comprova o discurso heróico que empresta à construção do Canal do Mar Branco. A documentação fotográfica produzida por ele pode ser inscrita no espaço do mito em virtude da estratégia adotada: ele não nega 0 emprego dos presos como mão-de-obra, pois the confere um significado regenerador. Desse modo, 0 artista fala do fato, mas o purifica, 0 inocenta, ao abolir toda complexidade e ao dar ao episódio uma clareza não alheia à naturalidade com o qual ele é apresentad $0^{66}$.

0 engajamento dos artistas na causa revolucionária, que os leva a apresentar a vida do país pelo prisma do mito, de uma narrativa que confere prioridade à imagem e à metáfora, ajuda o regime a oferecer uma imagem positiva de si, livre das contradições internas que caracterizavam o período de Stalin. Esse engajamento, no entanto, não é suficiente para proteger alguns deles das vicissitudes políticas e, sobretudo, dos expurgos que estavam ocorrendo desde 1936. Klutsis será uma das vítimas da política de repressão instaurada por Stalin. Sua biografia de revolucionário da primeira hora, que participou da tomada do Palácio de Inverno, integrou a guarda militar de Lenin e pôs o próprio trabalho a serviço do regime, transforma-se em evidência negativa diante da reconstrução da revolução levada a cabo por Stalin. Acusado de pertencer a um grupo nacionalista da Letônia, é preso e executado em $1938^{67}$.

É justamente nesse ano que Stalin publica a primeira edição de História do PCUS, cujos traços fundamentais são a falsificação e a manipulação dos eventos históricos e a invenção de tradições, de maneira a enfatizar o próprio papel heróico no âmbito da revolução. Rodtchenko participa desse clima de manipulação da memória: em sua cópia do livro $0 \mathrm{~s}$ dez anos do Uzbequistão cujo projeto gráfico havia elaborado em 1934, em colaboração com Stepanova -, obscurece com nanquim os rostos de líderes que haviam caído em desgraça ${ }^{68}$. Após o fechamento de USSR na stroike em 1941, Rodtchenko e Stepanova continuam a produzirálbuns fo tog ráficos de cunho oficial: De M oscou a Stalingrado (1943-1945); O s vinte e cinco anos do Caza quistão (1945-1947); Cinco anos de reservas de trabalho (1945-1947). Além disso, o artista ocupa um cargo oficial: em 1944, é nomeado diretor artístico da Casa da Técnica de M oscou.

Diante desses fatos, é difícil aceitar os argumentos de alguns histo riad o res que tend em a minimizar, quando não negar, o real co mp ro metimento de Rodtchenko com o regime stalinista. Alexander Laurientev, por exemplo, diz que a documentação da construção do $\mathrm{C}$ anal do $\mathrm{M}$ ar Branco era sujeita à censura: 0 artista só poderia fotografar cenas justificadas num plano de trabalho preliminar; 0 envio do material (negativos e provas) para publicação dependia de uma aprovação prévia. Esse argumento é bastante frágil, se for lembrado que o número especial de USSR na stroike e o álbum dedicado a o empreendimento do Báltico são publicados em 1933, enqua nto a documentação, iniciada em 1931 , estende-se por dois anos. Por outro lado, existem evidências de que Rodtchenko alterou várias fotografias para forjar alegorias de um trabalho não 
só produtivo como regenerador. Parece também frágil um outro tipo de argumento usado para justificar essa mesma colaboração, que acaba por contradizer a afirmação de Laurientev: tratar-se-ia de uma tentativa desesperada do artista para salvar a própria pele e para resgatar o próprio trabalho aos olhos das auto ridades ${ }^{69}$.

Lissitki, por sua vez, parece ter permanecido fiel ao regime até sua morte. Q uando falece em dezembro de 1941, ha via concluído o cartaz Produzam mais tanques, em a poio a o esforço bélico do país, dando mais uma demonstra ção de seu alinhamento à política simbólica oficial.

\section{REFERÊN CIAS}

ADAMS, B. Rodchenko's revolutionary vision. Art in America, New York, v. 86, n. 12, p. 56-63, 105, dec. 1998.

ADES, D. Photomontage. London: Thames \& Hudson, 1986.

ADORNO,T. W. Teoria estetica. Torino: Einaudi, 1977.

ARVATOV, B. Arte y producción. Madri: Alberto Corazón, 1973.

BARTHES, R. Mythologies. Paris: Seuil, 1970.

BOIS,Y.-A. El Lissitzky: radical reversibility. Art in America, New York, v. 76, n. 4, p. 160-181, apr. 1988.

BRIK, O.The photograph versus the painting. In: PHILLIPS, C. (Org.). Photography in the modern era:European documents and critical writings, 1913-1940. N ew York: The Metropolitan Museum of Art/Aperture, 1989, p. 213-218.

BUCHLOH, B. H. D. From faktura to factograp hy. October, Cambridge, n. 30, p. 83-118, 1984.

DICKERMAN, L. Camera obscura: socialist realism in the shadow of photography. October, Cambridge, n. 93, p. 139-153, 2000.

DORFLES, G. Nuovi riti, nuovi miti.Torino: Einaudi, 1965.

EGBERT, D. D. El arte en la teoría marxista y en la práctica soviética. Barcelona: Tusquets, 1973.

ELIADE, M. Aspects du mythe. Paris: Gallimard, 1975.

FABRIS,A. A fotomontagem como função política. História, São Paulo, v. 22, n. 1, p. 11-57, 2003.

FINIZIO, L. P. L'astrattismo costruttivo: Suprematismo e Costruttivismo. Roma-Bari: Laterza, 1990. 
HOFMANN,W. Da Babeuf a Marcuse: storia delle idee e dei movimenti sociali nei secoli XIX e XX. Milano: Mondadori, 1971.

LAURENTIEV, A. Alexander Rodchenko:photography 1924-1954. Köln: Könemann, 1995.

LODDER, C. El constructivismo ruso. Madrid: Alianza Editorial, 1987.

LUNACHARSKI, A.V. Las artes plásticas y la política en la Rusia revolucionaria. Barcelona: Seix Barral, 1969.

MARGOLIN, V. The strength for utopia:Rodchenko, Lissitzky, Moholy-Nagy -1917-1946. ChicagoLondon: The University of Chicago Press, 1997.

NAKOV, A. B. Back to the material: Rodchenko's photographic ideology. Artforum, New York, v. 16, n. 2, p. 38-43, oct. 1977.

p. 33-36.

Introducción. In:TARABUKIN, N. El ultimo cuadro. Barcelona: Gustavo Gili, 1977,

NEGRI, A. Il realismo: da Courbet agli anni venti. Roma-Bari: Laterza, 1989.

PHILLIPS, C. Una visión que resucita: la nueva fotografía europea de entreguerras. In: . La nueva visión:fotografía de entreguerras. Valencia: Ivam, 1995, p. 65-108.

ROBIN, R. Le réalisme socialiste: une esthétique impossible. Paris: Payot, 1986.

STEPANOVA,V. Photomontage. In:PHILLIPS, C. (Org.). Photography in the modern era:European documents and critical writings, 1913-1940. New York: The Metropolitan Museum of Art/Aperture, 1989, p. 234-237.

TAFURI, M. Progetto e utopia: architettura e sviluppo capitalistico. Roma-Bari: Laterza, 1973.

TARABUKIN, N.The art of the day. October, Cambridge, n. 93, p. 57-77, 2000.

. El ultimo cuadro. Barcelona: Gustavo Gili, 1977.

TUPITSY N, M. Gustav Klutsis: betw een art and politics. Art in America, New York, v. 79, n. 1, p. 41-47, jan. 1991.

WOOD, P. Realismos e realidades. In: FER, B. et al. Realismo, racionalismo, surrealismo: a arte no entreguerras. São Paulo: Cosac e Naify, 1998, p. 250-335.

Artigo apresentado em 08/2004. A provado em 08/2004. 